\title{
Impact of Climate Change Adaptation Strategies on Winter Wheat and Cropping System Performance across Precipitation Gradients in the Inland Pacific Northwest, USA
}

Tai M. Maaz ${ }^{1 *}$, William F. Schillinger ${ }^{2}$, Stephen Machado ${ }^{3}$, Erin Brooks ${ }^{4}$, Jodi L. Johnson-Maynard ${ }^{5}$, Lauren E. Young ${ }^{6}$, Frank L. Young ${ }^{7}$, Ian Leslie ${ }^{7}$, Ayana Glover ${ }^{4}$, Isaac J. Madsen ${ }^{1}$, Aaron Esser ${ }^{8}$, Harold P. Collins ${ }^{9}$ and William L. Pan ${ }^{1}$

${ }^{1}$ Department of Crop and Soil Sciences, Washington State University, Pullman, WA, United States, ${ }^{2}$ Department of Crop and Soil Sciences, Lind Dryland Research Station, Washington State University, Lind, WA, United States, ${ }^{3}$ Columbia Basin Agricultural Research Center, Adams, OR, United States, ${ }^{4}$ Biological Engineering, University of Idaho, Moscow, ID, United States, ${ }^{5}$ Department of Plant, Soil and Entomological Sciences, University of Idaho, Moscow, ID, United States,

OPEN ACCESS

Edited by:

Luuk Fleskens,

Wageningen University and Research

Centre, Netherlands

Reviewed by:

Saeedeh Nazari Nooghabi,

Tarbiat Modares University, Iran

Ana Iglesias,

Universidad Politécnica de Madrid,

Spain

${ }^{*}$ Correspondence:

Tai M. Maaz

tai.mcclellan@wsu.edu

Specialty section:

This article was submitted to Agroecology and Land Use Systems,

a section of the journal

Frontiers in Environmental Science

Received: 01 March 2017 Accepted: 01 May 2017

Published: 29 May 2017

Citation:

Maaz TM, Schillinger WF, Machado S,

Brooks E, Johnson-Maynard JL,

Young LE, Young FL, Leslie I,

Glover A, Madsen IJ, Esser A,

Collins HP and Pan WL (2017) Impact

of Climate Change Adaptation

Strategies on Winter Wheat and

Cropping System Performance across

Precipitation Gradients in the Inland

Pacific Northwest, USA

Front. Environ. Sci. 5:23.

doi: 10.3389/fenvs.2017.00023
${ }^{6}$ Washington State Crop Improvement Association, Pullman, WA, United States, ${ }^{7}$ Northwest Sustainable Agroecosystems Research (USDA ARS), Pullman, WA, United States, ${ }^{8}$ Department of Crop and Soil Sciences, Lind Research Station, Washington State University Extension, Ritzville, WA, United States, ${ }^{9}$ Grassland, Soil and Water Research Laboratory (USDA ARS), Temple, TX, United States

Ecological instability and low resource use efficiencies are concerns for the long-term productivity of conventional cereal monoculture systems, particularly those threatened by projected climate change. Crop intensification, diversification, reduced tillage, and variable $\mathrm{N}$ management are among strategies proposed to mitigate and adapt to climate shifts in the inland Pacific Northwest (iPNW). Our objectives were to assess these strategies across iPNW agroecological zones and time for their impacts on (1) winter wheat (WW) (Triticum aestivum L.) productivity, (2) crop sequence productivity, and (3) $\mathrm{N}$ fertilizer use efficiency. Region-wide analysis indicated that WW yields increased with increasing annual precipitation, prior to maximizing at $520 \mathrm{~mm} \mathrm{yr}^{-1}$ and subsequently declining when annual precipitation was not adjusted for available soil water holding capacity. While fallow periods were effective at mitigating low nitrogen $(\mathrm{N})$ fertilization efficiencies under low precipitation, efficiencies declined as annual precipitation exceeded $500 \mathrm{~mm} \mathrm{yr}^{-1}$. Variability in the response of WW yields to annual precipitation and $\mathrm{N}$ fertilization among locations and within sites supports precision $\mathrm{N}$ management implementation across the region. In years receiving $<350 \mathrm{~mm}$ precipitation $\mathrm{yr}^{-1}$, WW yields declined when preceded by crops rather than summer fallow. Nevertheless, WW yields were greater when preceded by pulses and oilseeds rather than wheat across a range of yield potentials, and when under conservation tillage practices at low yield potentials. Despite the yield penalty associated with eliminating fallow prior to WW, cropping system level productivity was not affected by intensification, diversification, or conservation tillage. However, increased fertilizer $\mathrm{N}$ inputs, lower fertilizer $\mathrm{N}$ use efficiencies, and more yield variance may offset and limit the economic feasibility of intensified and diversified cropping systems.

Keywords: intensification, diversification, fallow, precipitation, iPNW USA, cropping systems, conservation tillage 


\section{INTRODUCTION}

Ecological instability, high demand for inputs, and low resource use efficiencies are concerns for the long-term productivity of conventional cereal monoculture systems (Matson et al., 1997; Tilman, 1999). Crop intensification, diversification, reduced tillage, and variable $\mathrm{N}$ management are among the strategies proposed to mitigate and adapt monocultures to projected climate shifts (Burney et al., 2010; Smith and Olesen, 2010; Tilman et al., 2011; Powlson et al., 2014; Ponisio et al., 2015). Diversifying crop options may increase the resiliency of agroecosystems (Lin, 2011) and stabilize cropping systems vulnerable to a changing climate (Altieri et al., 2015) through agronomic (Johnston et al., 2005; Kirkegaard et al., 2008; Hansen et al., 2012; Seymour et al., 2012; Cutforth et al., 2013; Angus et al., 2015), economic (Entz et al., 2002; Zentner et al., 2002b, 2004), and environmental (Zentner et al., 2004; Gan et al., 2011; Davis et al., 2012) benefits. In the summer-dominate precipitation region of the North American Great Plains, soil conservation practices have enabled crop intensification through fallow replacement (Lafond et al., 1992; Anderson et al., 2003), which has increased opportunities to diversify crops (Halvorson et al., 1999; Zentner et al., 2002b; Tanaka et al., 2005; Roberts and Johnston, 2007), enhance $\mathrm{N}$ and water use efficiencies (Pikul et al., 2012). In addition to conserving soil water, the reduction or elimination of tillage is a strategy to combat water and wind erosion (Singh et al., 2012; Williams et al., 2014) in combination with continuous annual cropping (Thorne et al., 2003; Feng et al., 2011). Heterogeneous topography also challenges nutrient management due to significant variability in plant-soil-nutrient interactions and crop performance (Fiez et al., 1994, 1995) with opportunities for site specific $\mathrm{N}$ fertilizer management to mitigate differences in water and $\mathrm{N}$ use efficiencies across the landscape (Miao et al., 2011). A combination of these alternative cropping system strategies may increase productivity and economic returns (Tanaka et al., 2002; Alam et al., 2015; Babu et al., 2016), and multiple strategies may be needed (Kirkegaard and Hunt, 2010; Snapp et al., 2010).

The wheat producing region of the iPNW includes a steep precipitation gradient, making it an ideal area to study the influence of climate and management practices on wheat production. The iPNW is a highly productive wheat growing region that encompasses over 3 million ha in Washington, Idaho, and Oregon. The area is characterized by a Mediterranean-like climate, and $80 \%$ cropland largely relies on stored soil water to support dryland grain production (Pan et al., 2016b). A steep annual precipitation and temperature gradient, combined with complex topography, contributes to large-scale heterogenetic edaphic, and climatic conditions that delineate the region into three distinct classes of agroecological systems. Continuous, annual cropping systems predominate in cooler, wetter conditions in areas receiving $450-600 \mathrm{~mm}$ of annual precipitation, whereas a 2 -year grain-fallow rotation

Abbreviations: CV, coefficient of variation; iPNW, inland Pacific Northwest; SD, standard deviation; SW, spring wheat; $\mathrm{WW}$, winter wheat. dominates under drier, warmer conditions with $<330 \mathrm{~mm}$ (Pan et al., 2016b). The frequency of fallow decreases as dry and warm conditions become wetter and cooler, and growers may fallow once every 3 years in the fallowtransition systems in areas receiving between 300 and 450 mm (Schillinger and Papendick, 2008; Pan et al., 2016b). In the driest region, grain production requires irrigation. Wheat predominates in these dryland systems, which makes up $98 \%$ of crops grown in the grain-fallow systems, $89 \%$ in fallow transition, and $70 \%$ in the annual systems (Maaz et al., in press).

Over the last decade, average annual temperature in the Pacific Northwest has increased by $0.7^{\circ} \mathrm{C}$ (Mote et al., 2014), while the coldest winter night has risen by almost $2^{\circ} \mathrm{C}$ (Abatzoglou et al., 2015). Snowfall has also declined during this time period, with a decreasing proportion of total precipitation as snow (Kunkel et al., 2009). Assuming no changes in greenhouse gas emissions, climate models forecast a $5-15 \%$ increase in regional annual precipitation (Mote et al., 2014) with an increasing proportion occurring in winter and spring months and drier summers (Mote et al., 2014). Annual temperatures are also predicted to increase by $3-6^{\circ} \mathrm{C}$ by mid to late twenty-first century (Walden, 2014) with a greater degree of warming in the summer months (Abatzoglou et al., 2015). Warmer and drier summer conditions may have negative impacts on wheat productivity depending upon the extent of nutrient, heat, and water stress during critical growth stages (Rosenzweig et al., 2014; Asseng et al., 2015), although $\mathrm{CO}_{2}$ fertilization may counteract such stresses with some uncertainty (Erda et al., 2005; Guo et al., 2010; McGrath and Lobell, 2013). Given the potential impact of climate change, coordinated efforts are required to understand patterns in productivity and the potential for improving yields and resource use efficiency within these systems to ensure longterm resiliency.

The first objective of our study was to characterize WW productivity across the different cropping system zones of the iPNW. The second objective was to provide an initial assessment of the potential to improve $\mathrm{WW}$ and cropping system productivity and efficiencies across the iPNW upon (1) fallow reduction, (2) increasing crop diversity, and (3) adopting soil conservation practices, with a particular focus on responses in low-precipitation conditions. Our first hypothesis was that yields would increase with increasing annual precipitation before reaching a maximum prior and then declining. Our second hypothesis was that intensification through the reduction of fallow in the drier zones will reduce WW productivity and rotational yields, as well as increase variability. We anticipated that crop diversification would enhance productivity as WW yield potential increases, and we expected soil conservation practices, such as direct seeding and chemical (i.e., no-till) fallow, would improve crop productivity, particularly under low-precipitation conditions. Because of the reductions in WW yields in intensified rotations, we expected cropping system level productivity to offset any gains due to continuous cropping in intensified and diversified systems utilizing soil conservation practices. 


\section{MATERIALS AND METHODS}

Data from 11 sites and 8 independent studies conducted across the iPNW (Table 1) were utilized to determine trends in WW yields and the potential impacts of intensification, diversification, improved use efficiencies, and soil conservation. All soils were classified as silt loams; however, the available water holding capacity was lowest at the location with the highest precipitation due to the presence of dense, subsurface clay layers.

\section{Ralston, WA}

The Ralston study is located at the long-term research plots located southwest of Ritzville, WA, which was utilized to assess effects of soil conservation and fertilizer efficiencies. The long-term annual precipitation for the study site is 280 $\mathrm{mm} \mathrm{yr}^{-1}$. Information about previous crop rotations and site characterization were published by Young et al. (2015). In 2012 and 2013, the study contained four cropping systems, each replicated four times in a randomized complete block design. There were two complete sets of plots with fallow and crops present in any given year. Individual plots were $7.9 \times 152 \mathrm{~m}$. Cropping systems included standard-height (i.e., tall) WW (cv. Farnum) following conservation tillage fallow harvested with a cutter bar header, tall WW following no-till chemical fallow harvested with a stripper header, winter triticale (Triticosecale hexaploid L. cv. Trimark 099) following no-till chemical fallow harvested with a cutter bar, and winter triticale following no-till chemical fallow harvested with a stripper header.

\section{Moro, OR}

A long-term experiment was initiated in 2003 at the Oregon State University Sherman Station near Moro, OR, to evaluate traditional winter wheat-summer fallow cropping system under conservation tillage, intensified, and diversified cropping systems using no-till practices (Machado et al., 2015). Average annual precipitation at the site is $289 \mathrm{~mm}$. The experimental area consisted of 42 plots, each 15 by $105 \mathrm{~m}$, with 14 treatments of eight crop rotations in a randomized complete block design with three replications. In addition to WW-summer fallow, WW-notill chemical fallow, WW-spring barley (Hordeum vulgare L.)chemical fallow, WW-winter pea, and continuous WW were evaluated. All phases of the rotations were present every year. Details on management are reported by Machado et al. (2015).

\section{Ritzville, WA}

A long term experiment was initiated in 1997 on the Ronald Jirava farm near Ritzville, WA, to evaluate diverse cropping systems using no-till and conservation-till management (Schillinger et al., 2007; Schillinger and Paulitz, 2014). Average annual precipitation at the site is $292 \mathrm{~mm}$. The experiment consisted of 56 plots of 9 by $150 \mathrm{~m}$, six crop rotation treatments with all phases of all rotations present each year in a randomized complete block design with four replications. The traditional rotation was WW-summer fallow. Alternative rotations were $\mathrm{WW}$-spring wheat (SW)-summer fallow, WWsafflower (Carthamus tinctorius L.)-summer fallow, winter triticale -SW-chemical fallow, continuous no-till SW, and no-till SW-spring barley. Further details on treatments and management of the experiment are reported by Schillinger and Paulitz (2014).

\section{Davenport, WA}

Three- and four-year rotational field experiments were initiated at Davenport, WA, in 2011 to evaluate intensive cropping systems under no-till practices diversified with oilseeds and pulses. Average annual precipitation for the site is $353 \mathrm{~mm}$ $\mathrm{yr}^{-1}$. Field plots, measuring $3.7 \times 15 \mathrm{~m}$, were established in a randomized complete block designed with four replications with each phase of the rotation present each year, with 96 plots and 5 treatments. Data were collected following the initiation of the rotations in 2011.

\section{Pullman, WA and Davenport, WA}

Three-year field experiments were initiated at Pullman, WA and Davenport, WA, following wheat in 2011 and 2012 (Pan et al., 2016a) to determine the rotational effect of pulses on WW. The long-term average annual precipitation at Pullman is $517 \mathrm{~mm}$ $\mathrm{yr}^{-1}$. Field plots, measuring 2 by $15 \mathrm{~m}$, were established in a randomized complete block designed with four replications and seeded to spring canola (Brassica napus L.). In the following spring after canola, plots were split longitudinally ( 1 by $15 \mathrm{~m}$ ) and were randomly seeded with inoculated dry field pea (Pisum sativum L.) or SW. In the third year, WW was direct-seeded across the existing split-plot design following spring pea or SW harvest.

In 2013, a subsequent 2-year field experiment was initiated at Pullman, WA and Davenport, WA, to determine the effect of oilseed vs. pulses vs. SW on following WW yields. Field plots, measuring 2 by $15 \mathrm{~m}$, were established in a randomized complete block designed with four replications and seeded to spring canola, spring pea, and spring wheat. In the following year, WW (cv. Madsen at Pullman and Otto at Davenport) was direct-seeded across the existing plot design following spring crops.

\section{Kambitsch Farm, ID}

A long-term experiment at the University of Idaho Kambitsch farm, north of Genesee, ID, was established in 2000 to study the impact of conservation tillage on WW (Johnson-Maynard et al., 2007). The average annual precipitation at the farm is $695 \mathrm{~mm}$ $\mathrm{yr}^{-1}$. Prior to 2000 the land was managed using conventional methods. Tillage treatments (chisel plow and no-till, each with plots $20 \times 80 \mathrm{~m}$ ) were replicated four times across a hillslope running east to west (across the slope). Each tillage treatment was split into three crop zones planted to either pea/chickpea (Ciser arietinum L.), spring barley/wheat, or winter wheat. Tillage plots were $18 \times 80 \mathrm{~m}$. Crop subplots are $6 \times 80 \mathrm{~m}(1.2 \mathrm{~m}$ alley between tillage strips).

\section{Colfax, WA, Genesee, ID, Troy, ID, and Leland, ID}

A site-specific, precision agriculture study was initiated in 2011 southwest of Colfax, WA, southeast of Troy, ID, southeast of Genesee, ID and in Leland, ID. The project focused using 


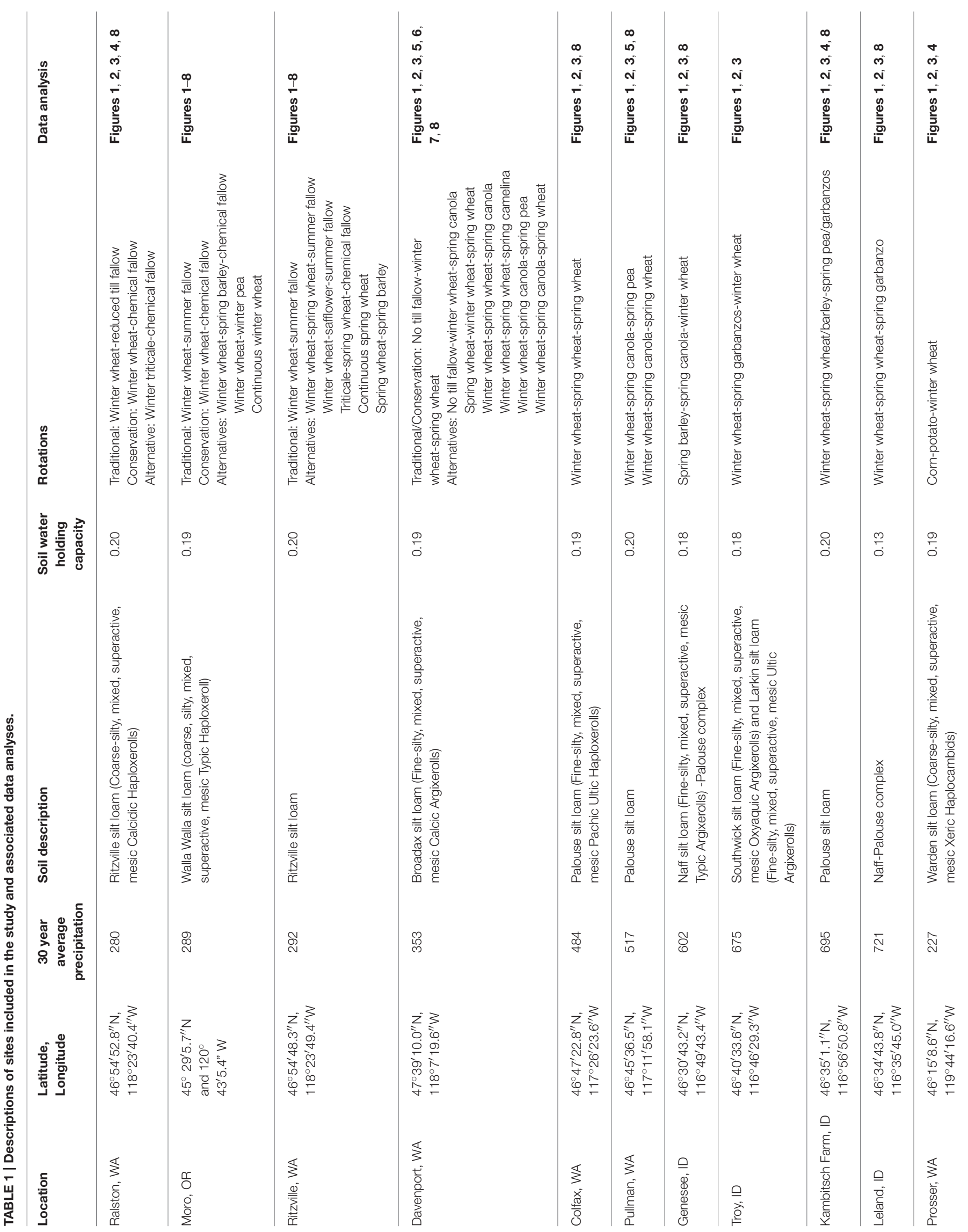




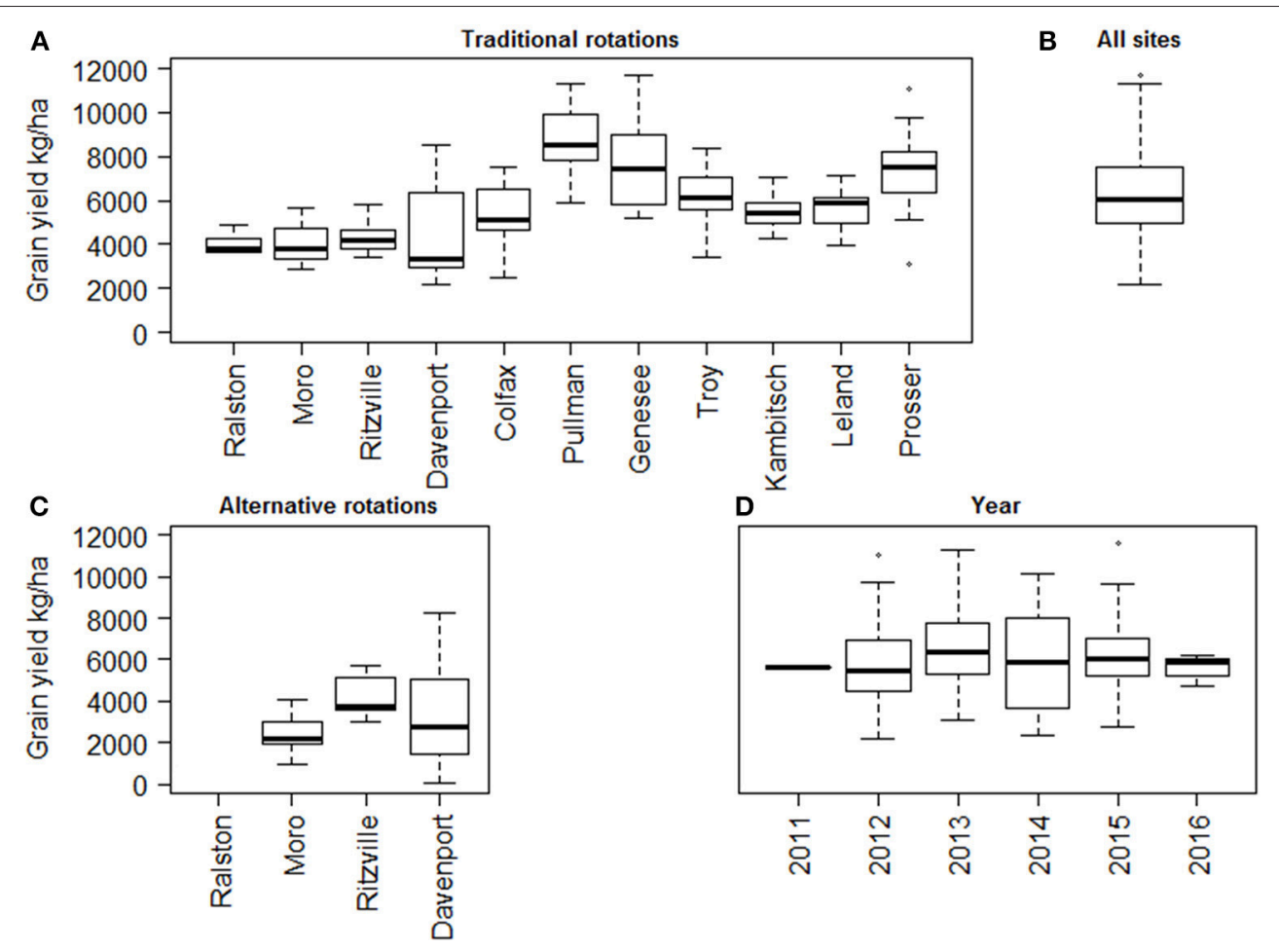

FIGURE 1 | Variance in winter wheat yields in (A) traditional rotations among the sites (ordered by increasing in long term mean annual precipitation of crop season), (B) across all site locations and year, (C) alternative rotations among the sites receiving $<350 \mathrm{~mm}^{2}$ annual precipitation $\mathrm{yr}^{-1}$, and (D) by year. The Prosser location received irrigation.

remote and proximal sensing to characterize and manage fieldscale variability in soil water, $\mathrm{N}$, and crop response across the landscape rather than plot-based research. Average annual precipitation is $484 \mathrm{~mm} \mathrm{yr}^{-1}$ at Colfax; $602 \mathrm{~mm} \mathrm{yr}^{-1}$, Genesee; $675 \mathrm{~mm} \mathrm{yr}^{-1}$, Troy; and $721 \mathrm{~mm} \mathrm{yr}^{-1}$, Leland. Within each farm, two catchments were selected such that the entire drainage area was captured within a single field. At each farm, one of these catchments were selected for intensive automated and manual monitoring. Each site was equipped with 12 spatially representative subsites which serve as the primary sampling locations within the watershed. A second catchment was reserved for validation purposes and was only monitored over the last 2 years of the project.

\section{Prosser, WA}

A 3-year field study was initiated in Prosser, WA, following wheat 2011 to assess conservation tillage and cover cropping effects on irrigated WW. Average annual precipitation at Prosser is 227 $\mathrm{mm} \mathrm{yr}^{-1}$. The cropping sequence was corn (Zea mays)-potatoes (Solanum tuberosum)-winter wheat. Winter wheat was irrigated with $458 \mathrm{~mm}$ in the spring and summer. Field plots measuring 4.9 by $15 \mathrm{~m}$, were established in a randomized complete block design with four replicates. The treatments were reduced tillage, reduced tillage winter cover crop, conventional tillage, and conventional tillage winter cover crop. Winter cover following sweet corn was triticale $(\times$ Triticolescale) and following potatoes was mustard
(Brassica hirta). The conventional tillage treatments were chisel disked prior to planting and post harvesting of every crop. The reduced tillage sequence was only chisel disked prior to planting potatoes and following potato harvest.

\section{Soil and Plant Sample Processing}

At Ritzville and Davenport, WA, composite soil samples from three replicates were taken every $30 \mathrm{~cm}$ down to $120 \mathrm{~cm}$ (or to an impermeable layer) with a giddings probe after harvest. At Moro, WA, soil samples were collected to a depth of $30 \mathrm{~cm}$ and composited. Ammonium and nitrate $\mathrm{N}$ were analyzed following $\mathrm{KCl}$ extraction and measured colorimetrically with a Quickchem 8000 Series FIA + system and AutoSampler (Lachat Instruments, Hach Company, Loveland, CO). Total C and $\mathrm{N}$ of composted soil samples collected in the first year of each study were measured by combustion in a $\mathrm{CN}$ analyzer.

At Prosser, Moro, Ritzville, Ralston, Davenport, Pullman, and Kambitsch, grain was harvested using commercial plot combines. Total above ground biomass was sampled from $1 \mathrm{~m}^{2}$ area at maturity and prior to determining harvest index to calculate residue biomass and $\mathrm{N}$ yields. Biomass samples were dried at $45-60^{\circ} \mathrm{C}$ for $48 \mathrm{~h}$, weighed, and threshed with a Vogel Stationary Grain Thresher, from which seeds, chaff, and stems were collected. Seeds were weighed to determine the harvest index. Seeds were ground with a Cyclone Sample Mill (Thomas Scientific, Swedesboro, NJ) for $\mathrm{C}$ and $\mathrm{N}$ analysis with a $\mathrm{C} / \mathrm{N}$ 

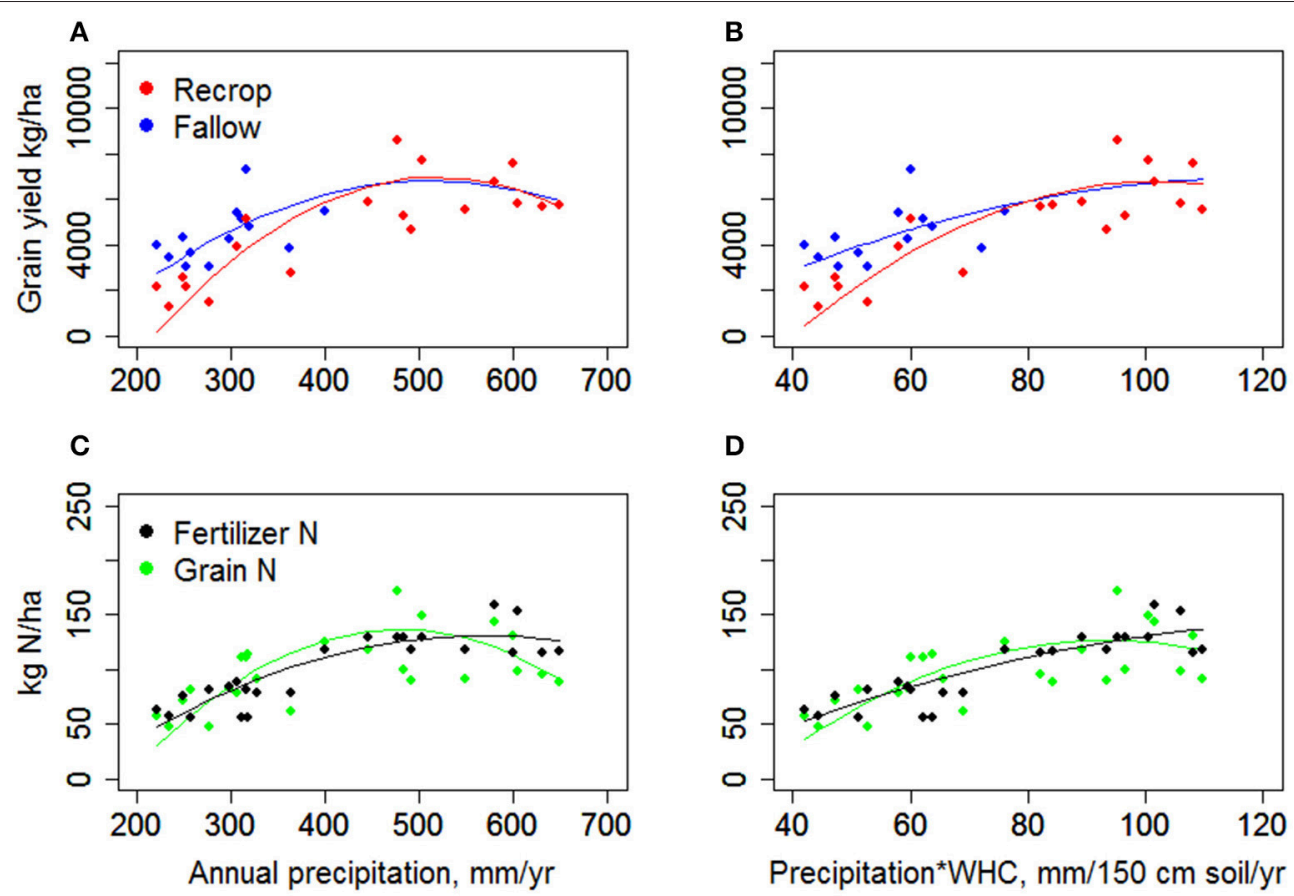

FIGURE 2 | Influence of annual precipitation on (A) winter wheat yields following crops or with fallow when annual precipitation $<350 \mathrm{~mm}$, (B) winter wheat yields following crops or fallow after adjusting annual precipitation for available soil water holding capacity, (C) winter wheat grain $\mathrm{N}$ accumulation and fertilizer $\mathrm{N}$ applications with increasing annual precipitation, and (D) winter wheat grain $\mathrm{N}$ accumulation and fertilizer $\mathrm{N}$ applications with adjusted annual precipitation based on the available water holding capacity.
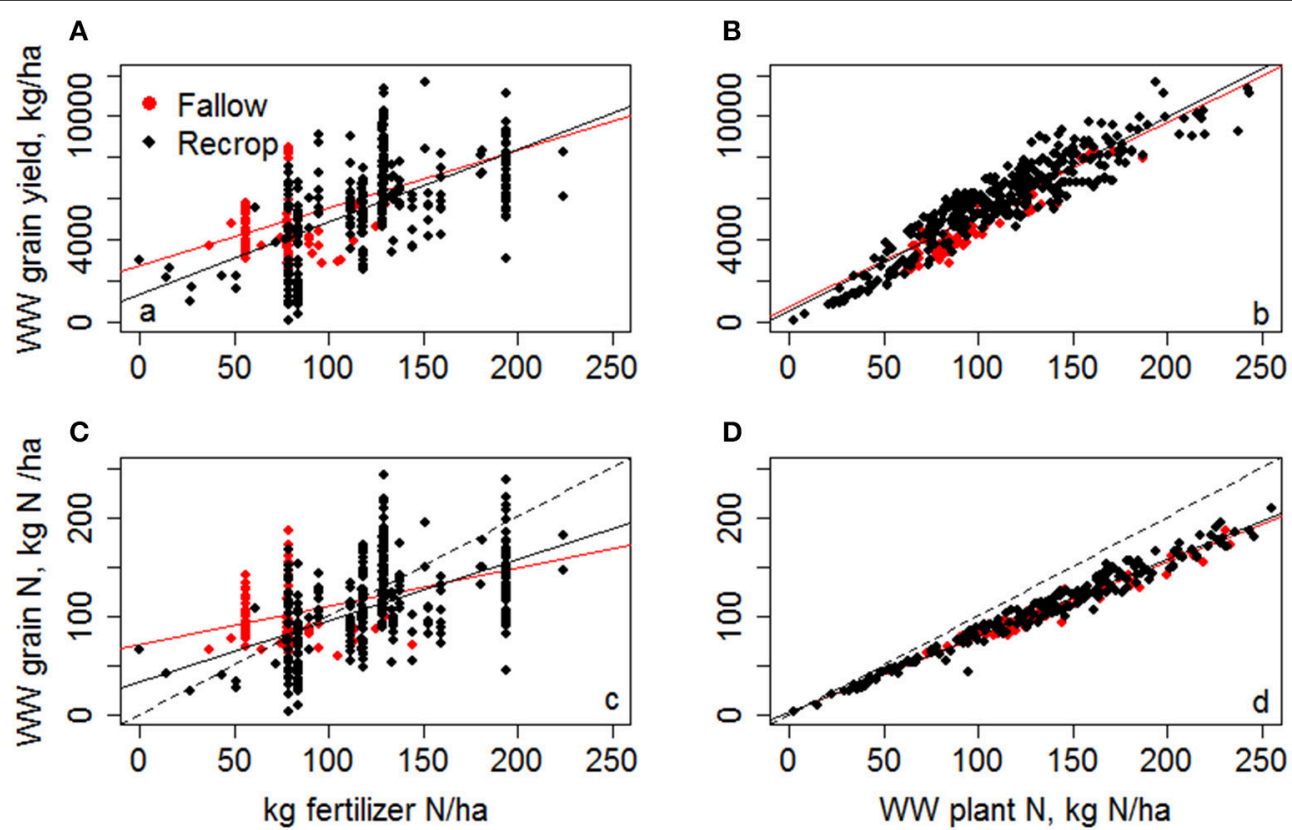

FIGURE 3 | Fertilizer use and N utilization efficiency of winter wheat in cropping systems research conducted in the inland PNW from 2011 to 2016, including (A) the response of winter wheat grain yields to fertilizer $\mathrm{N}$, (B) the utilization efficiency of grain $\mathrm{N}$ to produce grain, (C) ratio of grain $\mathrm{N}$ export to fertilizer $\mathrm{N}$ additions, and (D) winter wheat $\mathrm{N}$ harvest index. Wheat was differentiated by cropping sequence, and was grown after fallow or crops (recrop). Broken line represents the $1: 1$ relationship. 


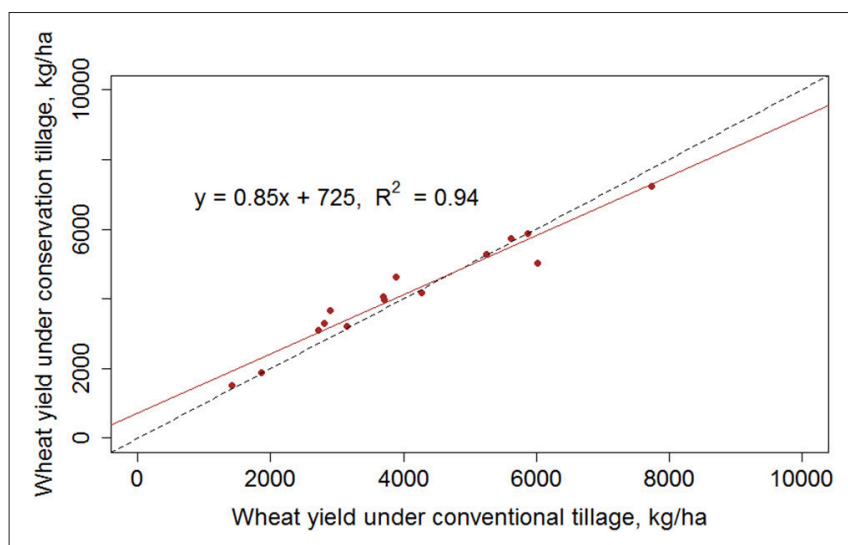

FIGURE 4 | Relative winter wheat yields in the inland PNW under conventional tillage ( $x$-axis) and conservation tillage (y-axis).

autoanalyzer (LECO Corp, St. Joseph, MI) at all sites except for Moro, in which grain protein was measured using the Inframatic 9200 (Perten Instruments, Hägersten, Sweden). Residue yields were calculated from the combined seed yields by applying the harvest index. Residue samples were ground with a Thomas Wiley mill (Thomas Scientific, Swedesboro, NJ) prior to C and $\mathrm{N}$ analysis (for all sites except Moro) by combustion using a Truspec Carbon and Nitrogen Analyzer (LECO Corporation, St. Joseph, MI). At Colfax, Genesee, Troy, and Leland locations, total above-ground biomass was determined at each of the 12 locations at harvest by hand-harvesting four $1 \mathrm{~m}^{2}$ plots at each site, and total grain yield within each $1 \mathrm{~m}^{2}$ locations was determined by threshing. All grain samples were analyzed for protein using Infratec 1241 Grain Analyzer (Foss, Hillerod, Denmark). Total nitrogen in the above ground residue was determined using a Truspec machine (LECO Corporation, St. Joseph, MI).

\section{Calculations and Statistical Analyses}

The mean, standard deviation (SD), and coefficient of variation (CV) were assessed for WW yields within and across all site locations. An analysis was conducted to assess variation in yields from traditional rotations (Table 1), in which fallow periods preceding WW when annual precipitation was $<350 \mathrm{~mm}$ $\mathrm{yr}^{-1}$, under both conventional and conservation tillage. Annual precipitation was calculated on a crop-year basis from September to August. In a separate analysis, variance was assessed for WW in alternative rotations when annual precipitation was $<350 \mathrm{~mm}$ $\mathrm{yr}^{-1}$ in which the fallow frequency was reduced to once every 3 years or WW (i.e., no fallow) followed crops. An analysis of variance was conducted with location as the fixed effect and annual precipitation, cropping sequence, and replicates as the random effects using the lme package in $\mathrm{R}$ (R Core Team, 2016).

To determine the effect of fallowing prior to WW, the response of WW yields to increasing annual precipitation were best fitted with a quadratic function, and two yield response curves were derived, including WW following crops vs. fallow when annual precipitation was $<350 \mathrm{~mm} \mathrm{yr}^{-1}$. To determine the efficiency of fertilization across the region in all systems, the relationship between annual precipitation and $\mathrm{N}$ fertilization rate, as well as grain $\mathrm{N}$ accumulation, was also best fitted with quadratic equations. These relationships were reassessed after annual precipitation was adjusted for the available water holding capacity of the soil, using data obtained from USDA NRCS Web Soil Survey (Soil Survey Staff, Natural Resources Conservation Service and United States Department of Agriculture, 2016). The regression-based predicted yields following fallow vs. recrop, as well as grain $\mathrm{N}$ accumulation vs. $\mathrm{N}$ fertilizer rate, were assessed by differencing the definite integrals (to calculate the areas underneath the curve) for precipitation ranges of 200-350, 350-500, and 500-650 $\mathrm{mm} \mathrm{yr}^{-1}$.

The comparative effects of cropping sequence on WW yields (WW after fallow vs. cereals/pulses/oilseeds), and WW following wheat vs. other cereals/pulses/oilseeds) were assessed using data collected in the iPNW described above relative to data obtained from a literature survey (Appendix 1). The literature survey included, but were not limited to, references provided by Angus et al. (2015) with a particular focus on wheat-fallow. The effect of tillage on wheat yields was also assessed for the iPNW. Winter wheat yields following break crops (i.e., non-wheat cereals, pulses, or oilseeds) were regressed against WW yields after fallow or SW/WW. Break crops included other cereal crops (barley and triticale), oilseeds [including canola, rapeseed, and camelina (Camelina sativa L. Crantz)], and pulse crops [including field pea, lentil (Len culinaris L.), garbanzo beans (Cicer arietinum L.), and lupin (Lupinus L.)]. In addition to the data collected in the present study, WW yields following break crops vs. wheat were compiled from iPNW data presented (Guy, 2013). For tillage comparisons, WW yields under conservation tillage were regressed against WW yields under conventional tillage for selected sites.

Linear regressions were used to assess the relationships among yields, fertilizer $\mathrm{N}$, plant $\mathrm{N}$, and grain $\mathrm{N}$ for WW after fallow (only when annual precipitation was $<350 \mathrm{~mm} \mathrm{yr}^{-1}$ ) vs. recropped WW for all sites. An analysis of covariance was conducted to determine interaction of cropping sequence with $\mathrm{N}$ responses, specifically the relationships between yield vs. fertilizer, grain $\mathrm{N}$ vs. fertilizer $\mathrm{N}$, yield vs. grain $\mathrm{N}$, and grain $\mathrm{N}$ vs. plant $\mathrm{N}$ using the stats package in R (R Core Team, 2016).

For cropping system level comparisons, energy outputs, total fertilizer inputs, and total grain $\mathrm{N}$ exports were summed over 3-4 years of observations. Annualized values were calculated to account for differences in the years of observations. Energy was calculated by multiplying grain yields by a conversion factor: legumes and cereals, by $15 \mathrm{MJ} \mathrm{kg}^{-1}$, and oilseed, by $25 \mathrm{MJ} \mathrm{kg}^{-1}$ (Zentner et al., 2004; Farine et al., 2010; Unakitan et al., 2010; Mousavi-Avval et al., 2011; KeshavarzAfshar and Chen, 2015). The variance of annualized energy outputs, fertilization, and grain $\mathrm{N}$ export was compared across increasingly intensified cropping systems at Moro, OR, Ritzville, WA, and Davenport, WA, all of which received $<350 \mathrm{~mm}$ $\mathrm{yr}^{-1}$ within the study period. Finally, an analysis of covariance was conducted to determine interaction of cropping sequence with rotational $\mathrm{N}$ responses, specifically the relationships between total energy output vs. total fertilizer input, total grain $\mathrm{N}$ export vs. total fertilizer input, total energy output 


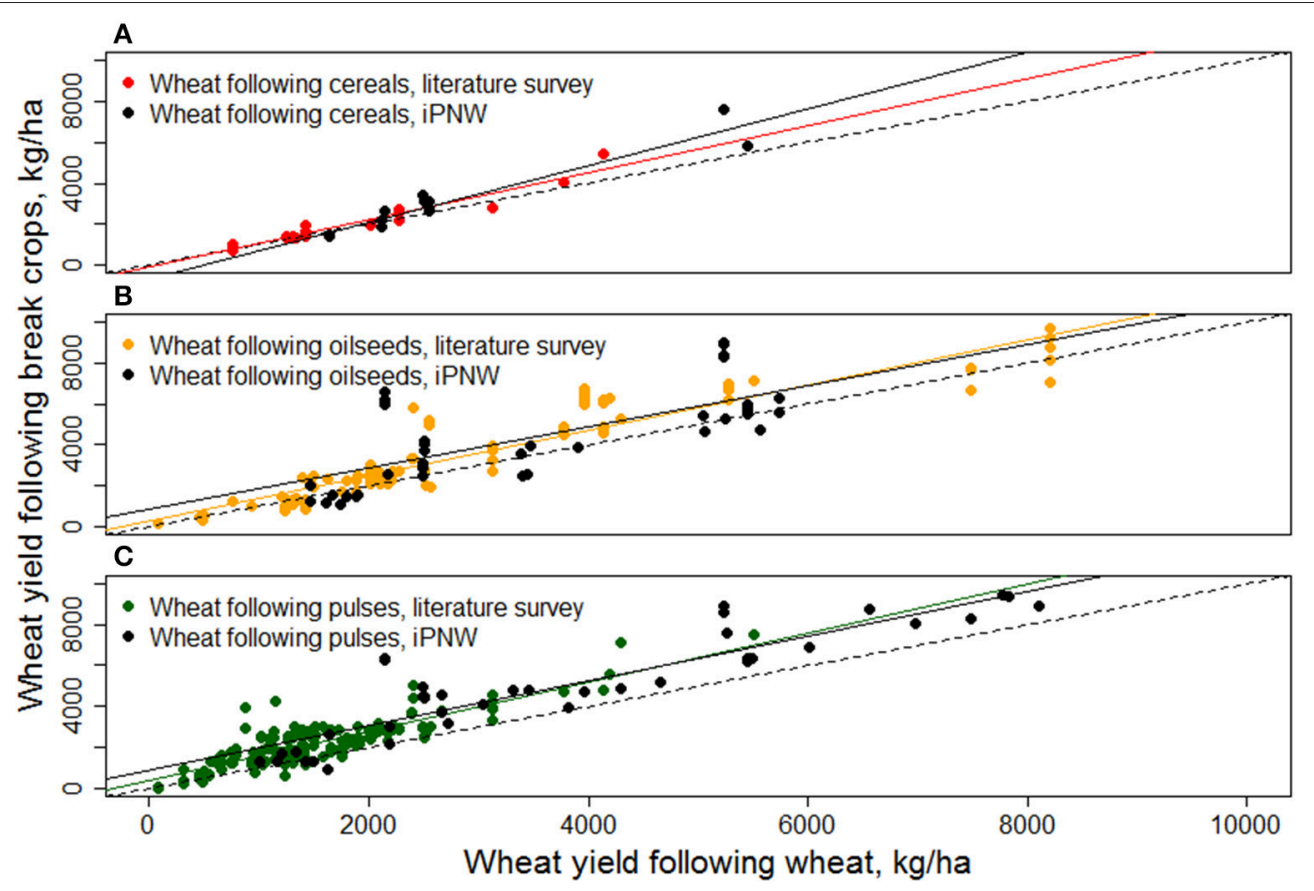

FIGURE 5 | Increase in winter wheat yields in a literature survey of predominately fallow systems and in the inland PNW following other cereals (A) , oilseeds (B), and pulses (C) (y-axis) vs. wheat following wheat ( $x$-axis).

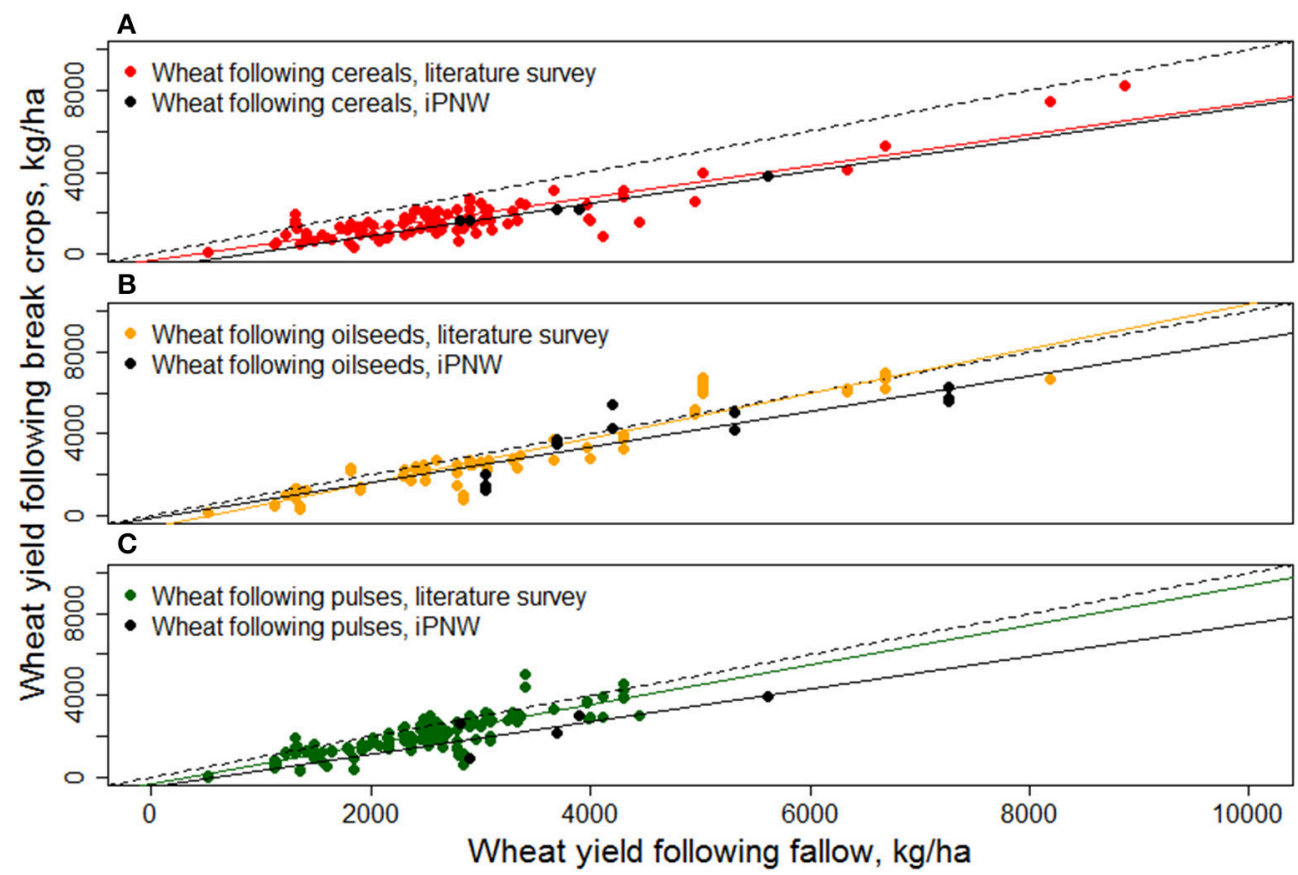

FIGURE 6 | Literature survey of wheat yields following fallow (y-axis) vs. alternative crops, including cereals (A), oilseeds (B), and pulses (C) (y-axis). Fallow replacement by oilseeds, pulses, and other cereals was also assessed in inland PNW.

vs. total grain $\mathrm{N}$, and total grain $\mathrm{N}$ export vs. total plant $\mathrm{N}$ uptake using the stats package in $\mathrm{R}$ ( $\mathrm{R}$ Core Team, 2016).
At Moro, Ritzville and Davenport, multi-year cropping system $\mathrm{N}$ budgets were constructed. Inputs included pre-plant inorganic $\mathrm{N}$ summed in the $120-\mathrm{cm}$ soil profile (or $30-\mathrm{cm}$ at Moro), 

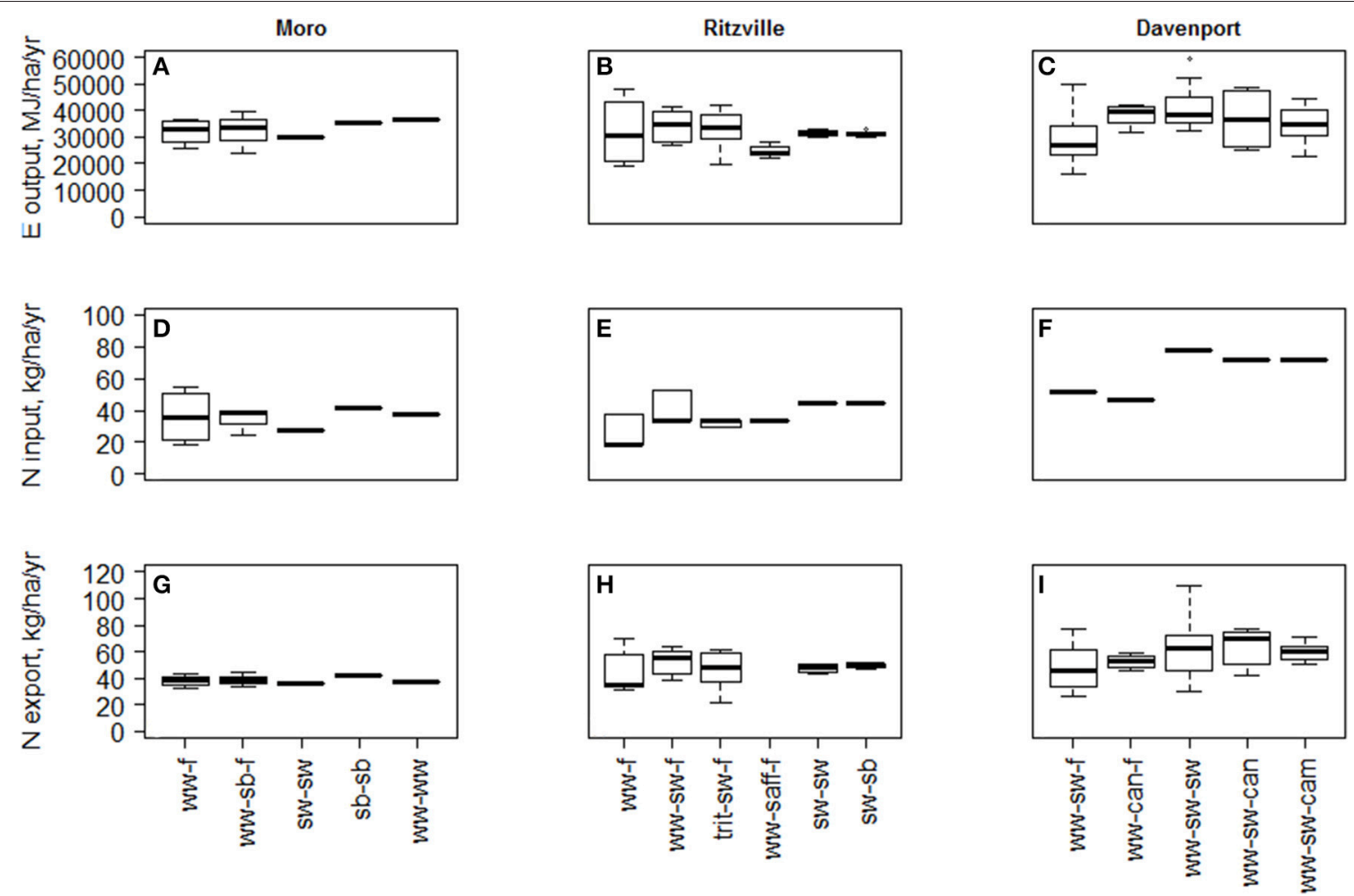

FIGURE 7 | Rotational fertilizer $\mathbf{N}$ inputs, energy outputs, and total grain $\mathbf{N}$ removal at Moro (A,D,G), Ritzville (B,E,H), and Davenport (C,F,I), respectively, in intensified and diversified conservation cropping systems research. Rotations are more intensified moving left to right of each graph. Inputs and outputs were summed over 3 years of observations, and annualized by dividing sums by years of observation. f, fallow; ww, winter wheat; sw, spring wheat; can, spring canola; cam, spring camelina; trit, winter triticale; saff, spring safflower.

total $\mathrm{N}$ fertilizer applied, and estimated $\mathrm{N}$ mineralized based on soil organic matter (described by Pan et al., 2016a). Outputs included total crop $\mathrm{N}$ uptake and post-harvest inorganic $\mathrm{N}$ in the $120-\mathrm{cm}$ soil profile. Nitrogen balance was determined by subtracting $\mathrm{N}$ outputs from $\mathrm{N}$ inputs. The fertilizer $\mathrm{N}$ balance was calculated by subtracting rotational grain $\mathrm{N}$ from total fertilizer $\mathrm{N}$ inputs.

\section{RESULTS AND DISCUSSION \\ Winter Wheat Productivity along a Precipitation Gradient}

In the iPNW, water is the most limiting resource in crop production due the region's semi-arid Mediterranean-like climate and steep rainfall gradient within the rain shadow of the Cascade Mountains (Schillinger and Papendick, 2008). As a result, yield potential of WW varies along the regional gradient in annual precipitation (Cook, 1986). Schillinger et al. (2008) determined that modern wheat cultivars can reproduce (e.g., yield grain) with $61 \mathrm{~mm}$ of available water in the iPNW, and WW yields improved by almost $20 \mathrm{~kg} \mathrm{ha}^{-1}$ for every millimeter gain in available water as available soil water increased from 60 to 350 $\mathrm{mm}$. However, a regional assessment of WW grain yield along the full extent of the annual precipitation gradient in the iPNW is lacking.
We found that WW yields varied considerably across and within the 11 locations (Figure 1A) with annual precipitation ranging from 220 to $650 \mathrm{~mm} \mathrm{yr}^{-1}$, with an overall mean of WW in traditional rotations of $\sim 6,000 \mathrm{~kg} \mathrm{ha}^{-1}$ and a CV of $31 \%$ (Figure 1B, Table 2). The regional variability in WW yields was consistent from 2012 to 2015 (Figure 1D). Annual precipitation and field position (plot or replicate) contributed similarly to the variability in WW within sites (Table 2). Winter wheat yield means were similar to or higher in the traditional fallow rotations than intensified, alternative rotations (Figure 1C), and the stability of WW yields declined, as indicated by the increase in $\mathrm{CV}$, in intensified rotations (Table 2).

Winter wheat yields responded significantly to annual precipitation (Figure 2A). Summer fallowing prior to WW reduced the yield response to annual precipitation in comparison with intensified WW production following cereal, oilseeds, and pulse crops substituting summer fallow. As a result, annual precipitation explained more of the variation in the WW yields when following crops $\left(R^{2}=0.53\right)$ than fallow $\left(R^{2}=0.31\right)$. While the fallow frequency (every other year vs. once every 3 years) did not affect the yield response, foregoing fallow prior to WW resulted in an integrated loss of $263 \mathrm{Mt}$ of $\mathrm{WW}$ yield $\mathrm{ha}^{-1}$ when annual precipitation ranged from 200 to $350 \mathrm{~mm}$ $\mathrm{yr}^{-1}$. Ultimately, WW production in the fallow cropping system is restricted by stored soil water plus April, May, and June 

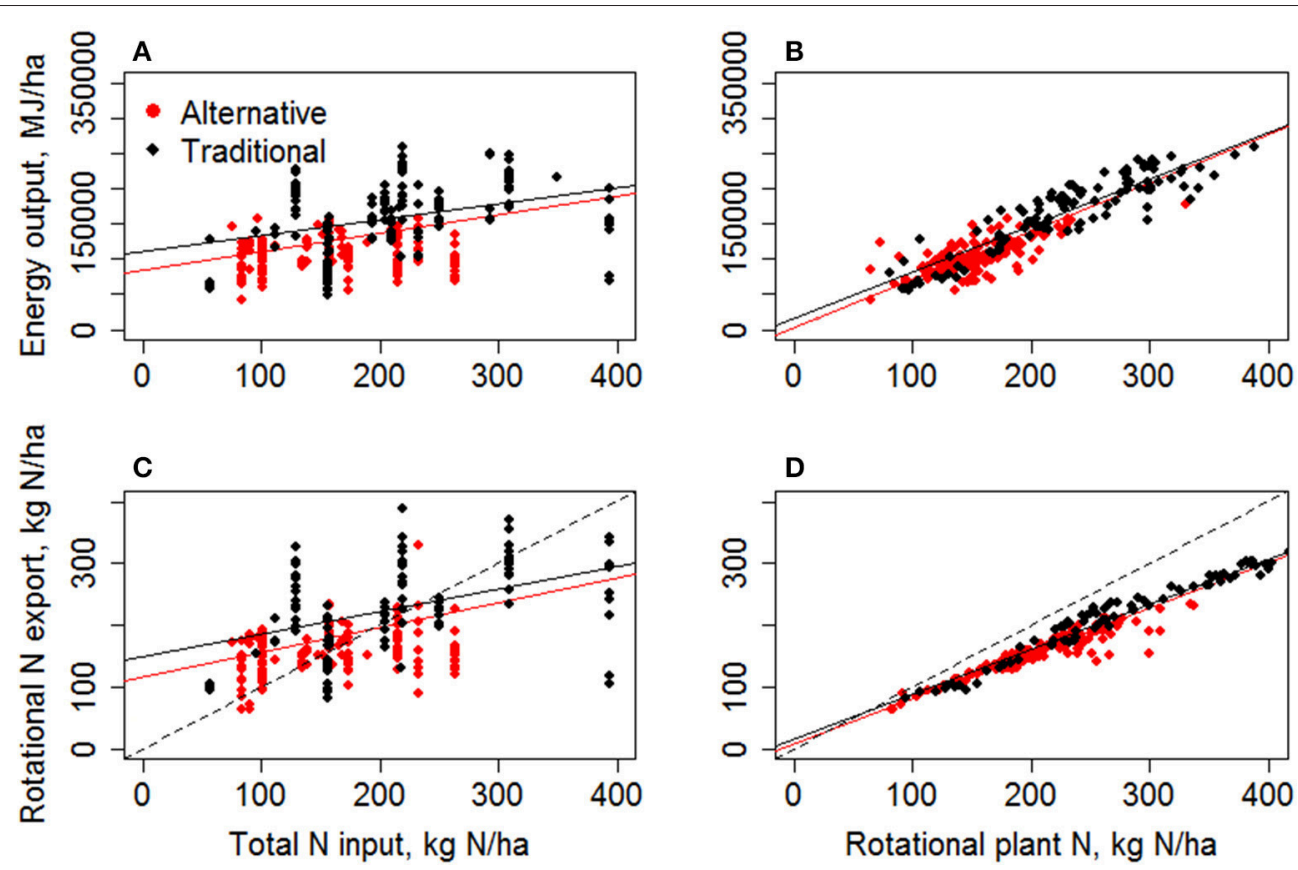

FIGURE 8 | Rotational nitrogen use efficiency of cropping systems in the inland PNW from 2011 to 2016, including (A) the response of rotational energy outputs to total fertilizer $\mathrm{N}$ additions, (B) the rotational utilization efficiency of grain $\mathrm{N}$ to produce energy, (C) ratio of rotational grain $\mathrm{N}$ export to total fertilizer $\mathrm{N}$ additions, and (D) rotational N harvest index. Traditional rotations include WW-summer fallow and WW-CF rotations at Ralston, Moro, and Ritzville, and WW-SW-CF at Davenport and all rotations listed in Table 2. Alternative rotations replaced WW-F through a reduction or elimination of fallow when precipitation was $<350$ mm $\mathrm{yr}^{-1}$. Broken line represents the 1:1 relationship.

rainfall; overwinter stored soil water dependent upon soil depth. Furthermore, previous studies have shown that the precipitation storage efficiency of fallowing in the iPNW is generally around 30\% (Wuest and Schillinger, 2011).

As annual precipitation increases, the topography becomes increasingly sloping, and soil biology changes. Earthworms may be observed above $330-370 \mathrm{~mm}$ of mean annual precipitation (Walsh and Johnson-Maynard, 2016), and soil organic matter increases in the topsoil (Morrow et al., 2017). We determined that WW yields reached a maximum of $6,800 \mathrm{~kg} \mathrm{ha}^{-1}$ at $520 \mathrm{~mm}$ $\mathrm{yr}^{-1}$, within the annual cropping region where precipitation is adequate to economically support crops every year (Figure 2A). The decline in WW yields after reaching the maximum may be due to various factors that contribute to an increase in the actual yield gap under more favorable conditions, such as increasing incidences of pests, disease, crop lodging, and nutrient deficiencies (Cook, 1986). Furthermore, topographic complexity varies across the region leading to differences in soil properties (Horner et al., 1957). As precipitation increases, the presence of finer-textured silty-clay and clay-loam soils with dense $(\sim 1.65$

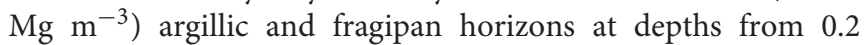
to $1.2 \mathrm{~m}$ below the soil surface can restrict vertical drainage and root penetration leading to the development of seasonal perched water tables (McDaniel et al., 2001; Brooks et al., 2012). These argillic and fragipan soils are generally found where mean annual precipitation exceeds $600 \mathrm{~mm}$ and have a limited soil water holding capacity due to the presence of dense subsurface clays (Brooks et al., 2012). In the Paradise Creek Watershed of North Idaho, which receives $650 \mathrm{~mm}$ annual precipitation $\mathrm{yr}^{-1}$, precipitation use efficiency is reduced by both restrictive layers, as well as winter runoff when soils saturate and frozen soils reduce infiltration (Brooks et al., 2010). Timely May and June precipitation is particularly critical in wheat production across the iPNW (Schillinger et al., 2008). Therefore, the soil constraints in the highest precipitation zone add additional risk to annual cropping as these shallow argillic and fragipan soils dry out faster and experience more water stress without adequate precipitation in May and June. The constraint of available soil water in the highest precipitation zones is evident when annual precipitation is adjusted for available water holding capacity (Figure 2B), and yields attain a plateau with the range of observed data rather than declining.

\section{Winter Wheat Response to Fertilizer along a Precipitation Gradient}

The interaction between WW yields and N fertilizer use efficiency has also never been examined across the extent of the iPNW's precipitation gradient. However, the regional soil and climatic properties have also served as the basis for the hypothesized interaction between $\mathrm{N}$ use efficiency and annual precipitation outlined by Pan et al. (2007). As precipitation increases in the region, root growth and yields become less limited by drought conditions, and $\mathrm{N}$ use efficiency increases as plants recover increasing amounts of fertilizer $\mathrm{N}$ from the topsoil. Therefore, 
TABLE 2 | Mean and variance of winter wheat produced at 11 site locations in the inland Pacific Northwest region.

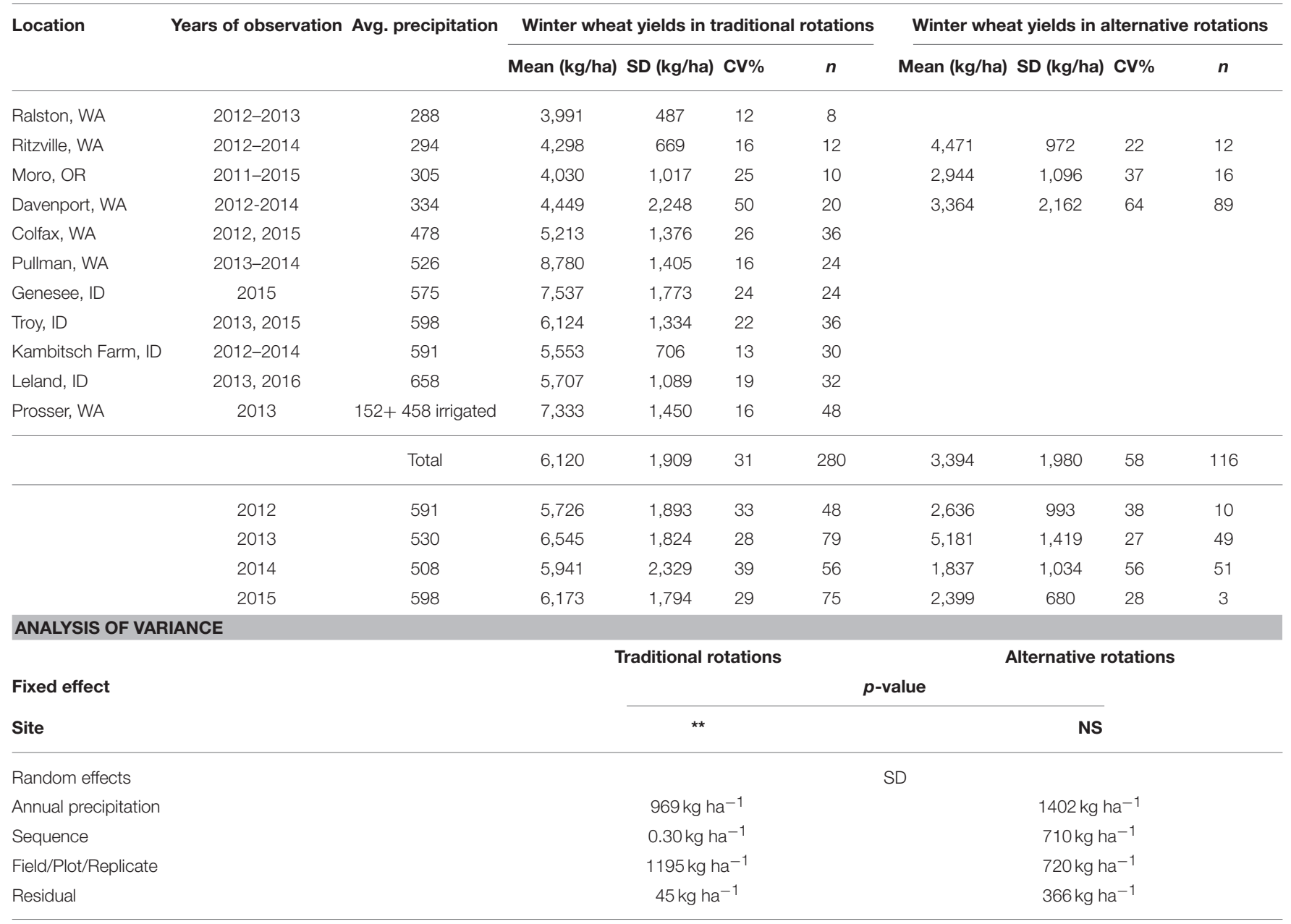

Rotations are listed in Table 1. When annual precipitation was $<350 \mathrm{~mm} y r^{-1}$, rotations were differentiated as traditional $W W$ - $F$ at Ritzville and Moro and WW-SW-F at Davenport. Alternative rotations were characterized by a reduction or elimination of fallow at these particular sites.

fallow periods are practiced to mitigate inefficiencies. A decline in $\mathrm{N}$ use efficiency was predicted by Pan et al. (2007) under increasingly high precipitation due to expected $\mathrm{N}$ losses in runoff, leaching, and denitrification pathways, in addition to limitations in rooting depth due to the presence of restrictive subsoil clay layers.

Our findings support these hypothesized interactions. First, annual precipitation explained most of the variance in fertilizer $\mathrm{N}$ rates $\left(R^{2}=0.67\right)$, and $39 \%$ of the variance in the accumulation of grain $\mathrm{N}$ (Figure 2C). Grain $\mathrm{N}$ increased with annual precipitation, prior to reaching a maximum at $480 \mathrm{~mm} \mathrm{yr}^{-1}$ before declining. Similar to yield trends, the decline in grain yield at high levels of precipitation was moderated by adjusting for available soil water holding capacity (Figure 2D). The regression analyses predicted similar amounts of $\mathrm{N}$ were applied as fertilizer and exported in grain when annual precipitation ranged from 200 to $350 \mathrm{~mm}$, corresponding with grain $\mathrm{N}$ to fertilizer ratios were $>1$. These high fertilization efficiencies were the result of residual $\mathrm{N}$ carryover and the recycling of mineralized $\mathrm{N}$, particularly for WW after fallow. As a result, fallow periods were not only instrumental in maintaining high yields through soil water storage, but also to reducing $\mathrm{N}$ deficiencies, as discussed by Pan et al. (2016a). High efficiencies of fertilization were also observed between 350 and $500 \mathrm{~mm} \mathrm{yr}^{-1}$, in which the integrated grain $\mathrm{N}$ export exceeded fertilizer $\mathrm{N}$ by $2,000 \mathrm{~kg} \mathrm{~N} \mathrm{ha}^{-1}$. However, fertilization inefficiencies declined when annual precipitation exceeded $480 \mathrm{~mm}$. The regressions predicted greater amounts of fertilizer were applied than removed in grain, with an integrated fertilizer $\mathrm{N}$ deficit of $2,650 \mathrm{~kg} \mathrm{~N} \mathrm{ha}{ }^{-1}$ from 500 to $650 \mathrm{~mm}$ $\mathrm{yr}^{-1}$. As fertilization increased beyond this maximum (120$150 \mathrm{~kg} \mathrm{~N} \mathrm{ha}{ }^{-1}$ ), the grain $\mathrm{N}$ to fertilizer ratios were $<1$. Fall and spring applications of fertilizer are recommended under high precipitation, but current extension guides suggest splitting a predetermined $\mathrm{N}$ fertilization rate rather than fine-tuning fertilizer management through tactical in-season applications or variable rates based on crop performance indicators (Mahler, 2007). Furthermore, these findings highlight the opportunity to investigate the utilization of nitrification inhibitors in soils of the inland Pacific Northwest with high risks of nitrate leaching or denitrification (Abalos et al., 2014). 


\section{Opportunities for Site-Specific N Management}

In addition to regional variability, we observed a considerable amount of within-site variability in WW productivity (Table 2 ), even at a field or plot scale. While a portion of this variability was teased out by differences in year-to-year precipitation, other environmental, genetic, and management factors contribute to within-site variability, such as landscape elevation, slope, aspect (Mulla et al., 1992; Fiez et al., 1994; Yang et al., 1998), subsoil constraints (Robertson et al., 2016), spring rainfall (Schillinger et al., 2008), crop rotation (Hammel, 1995), nutrient availability (Fiez et al., 1995), onset of drought and temperature stress (Gizaw et al., 2016), and crop genetics (Schillinger et al., 2008). Despite the heterogeneity of the landscape, iPNW growers still commonly apply single rates of fertilizer, particularly in the higher precipitation areas (Mahler et al., 2014). The need for sitespecific $\mathrm{N}$ management across the entire region is warranted, as evidenced by $\mathrm{N}$ fertilizer rate explaining only $35 \%$ of WW yield (Figure $3 \mathrm{~A}$ ) and $28 \%$ of grain $\mathrm{N}$ variability (Figure $3 \mathrm{C}$ ) when WW followed crops, and $21 \%$ of the variation in yield and $11 \%$ of grain $\mathrm{N}$ accumulation when WW followed fallow when precipitation was $<350 \mathrm{~mm} \mathrm{yr}^{-1}$.

In contrast, our analysis indicated that crop $\mathrm{N}$ was a consistent and reliable indicator of yield and grain protein, and may be a useful evaluation tool for site-specific $\mathrm{N}$ management in the iPNW. Across all data, grain $\mathrm{N}$ accumulation was closely correlated with the synthesis grain biomass (Figure 3B) and total above-ground plant N (Figure 3D) across all data, regardless of location, years, fertilizer rate, and previous crop, with $R^{2}$ values ranging from 0.80 to 0.98 . Magney et al. (2016a) demonstrated that in-season canopy monitoring using daily Normalized Difference Vegetation Index (NDVI) data could be used to explain $83 \%$ of yield variance and $80 \%$ of grain $\mathrm{N}$ accumulation. Total $\mathrm{N}$ in the biomass and grain has also been shown to be highly correlated to vegetation indices, particularly using red-edge bands, acquired from high resolution $(5 \times 5$ m) satellite imagery (Magney et al., 2016b). Therefore, precision agriculture based on plant-based sensing opportunities may be used in combination with tactical nutrient management to optimize wheat performance. Ultimately, these data can be utilized by decision support tools emerging for the region which allow growers to systematically evaluate their site specific $\mathrm{N}$ management practices based on performance criteria, and to diagnose conditions that contribute to suboptimal performance (Brown et al., 2015).

\section{Winter Wheat Productivity under Alternative Practices}

The traditional WW-summer fallow system was developed as an economically feasible strategy to accumulate water and N, manage weeds, and mitigate risk associated in low precipitation areas of the iPNW (Leggett et al., 1974; Bolton and Glenn, 1983). Crop diversity is largely lacking in the iPNW and fallow periods remain common in the low and intermediate precipitation cropping systems, and a decrease in species richness has also been reported along the diminishing mean annual precipitation gradient in other Mediterranean-like, semi-arid regions (Koocheki et al., 2008). The lack of crop diversity may be contrasted with other major wheat belts, such as the dryland systems of Canada and Australia (Cook et al., 2002; Zentner et al., 2002b; Conley et al., 2004; Kirkegaard et al., 2008). For instance, in the semi-arid region of Canada, the prevalence of fallow has decreased from 50 to $15 \%$ since the 1970s, coinciding with the development of chemical weed management and the adoption of direct seeding practices (Zentner et al., 2002a). The intensification of crop rotations enabled the expansion of pulse crops in semi-arid Canada (McVicar et al., 2000), which performed well in water-stressed environments of the Canadian prairies dominated by summer rainfall (Angadi et al., 2008; Cutforth et al., 2009; Bueckert and Clarke, 2013). Furthermore, the shallower rooting depth of pulse crops compared to cereals left behind deep residual water to support subsequent cereal and oilseed crops (Gan et al., 2009). By the late 1990s, research on pulse crops highlighted the rotational benefits of pulses to cereals (Miller et al., 2003) as a means to economically intensify crop rotations in Canada's semi-arid zone. These developments provide the rationale for assessing the effects of reduced tillage, crop diversity, and intensified of wheat-based systems in the iPNW.

\section{Conservation Tillage}

The adoption of conservation tillage practices was instrumental in intensifying and diversifying cropping systems in the Northern Great Plains (Zentner et al., 2002a). Across five locations in the iPNW, the adoption of conservation tillage practices was tightly correlated with WW productivity under conventional tillage practices (Figure 4). We found that conservation tillage increased WW yields at lower yield potentials, which diminished as yield potential increased (y-intercept of $725 \pm 257 \mathrm{~kg} \mathrm{ha}^{-1}$ with a regression slope of 0.85 ). However, conservation tillage practices were not effective at mediated the WW yield loss associated with fallow elimination. Similarly, Williams and Robertson (2016) at an $430 \mathrm{~mm}$ annual precipitation site reported that WW yields, as well as precipitation use efficiency, were not affected by tillage practice in long-term plots, whereas WW following crops had significantly lower yields and precipitation use efficiency.

\section{Crop Diversity}

In a review of the literature, Angus et al. (2015) reported that fallow periods were instrumental in increasing wheat yields at low yield potentials, whereas break crops were more effective at enhancing wheat yields at higher yield potentials $(>1,700 \mathrm{~kg}$ $\mathrm{ha}^{-1}$ ) relative to wheat following wheat. In our survey of the literature (Appendix 1), wheat yields were enhanced to a greater extent following oilseed (Figure 5B) and pulse (Figure 5C) break crops than cereals (Figure 5A) even at low yield potentials, which increased with greater yields (y-intercept $>0$ and slope $>1$ ) (Table 3). In comparison, the advantage of wheat following other cereal break crops rather than wheat was only observed at high yield potentials. In the iPNW, the effect of break crops were within the range reported in the literature (Figure 5), and the response of WW following pulses was greater than oilseeds and 
cereal crops, particularly due to influential observations pulse and oilseed crops at high and low yield potentials.

\section{Crop Intensification}

There were two means of intensifying crop rotations in this study. The first strategy was to eliminate fallow altogether, and continuous cropping practiced instead, whereas the second was to reduce the frequency of fallow from every other year to once every 3 years. In this scenario, WW is grown after fallow, while a spring crop follows WW. The effect of fallow elimination prior to WW reduced yields in the iPNW, which is within the range reported in the literature (Figure 6). However, within our dataset, differences in trends between the iPNW and the literature were observed. The substitution of summer fallow in the iPNW led to reductions in WW yield potential regardless of break crop (cereal vs. oilseed vs. pulse), as indicated by the negative $y$-intercepts and regression slopes of $<1.0$ (Table 4). In contrast, the intensification with cereals led to the greatest reduction in wheat yields reported in the literature (Figure 6A), particularly at higher yield potentials with a regression slope of 0.76 (Table 4). Yet, when wheat followed oilseeds (Figure 6B) and pulses (Figure 6C) rather than fallow, wheat yields reported in the literature were reduced to a lesser extent across a range of yield potentials-approximately $600 \mathrm{~kg} \mathrm{ha}^{-1}$ following oilseeds

TABLE 3 | Regression parameters for the linear relationship between winter wheat yield following other cereals, oilseeds, or pulses and wheat following wheat.

\begin{tabular}{lcccc}
\hline & $\boldsymbol{R}^{\mathbf{2}}$ & Slope & Intercept & $\boldsymbol{n}$ \\
\hline \multicolumn{2}{l}{ LITERATURE SURVEY } & & & \\
Wheat-cereal & 0.94 & $1.15 \pm 0.08^{\star \star \star}$ & $-85 \pm 158 \mathrm{NS}$ & 18 \\
Wheat-oilseed & 0.87 & $1.10 \pm 0.04^{\star \star \star}$ & $303 \pm 147^{\star}$ & 105 \\
Wheat-pulse & 0.75 & $1.20 \pm 0.06^{\star \star \star}$ & $362 \pm 98^{\star \star}$ & 162 \\
PNW & & & & \\
Wheat-cereal & 0.92 & $1.39 \pm 0.12^{\star \star \star}$ & $-692 \pm 349 \mathrm{NS}$ & 14 \\
Wheat-oilseed & 0.49 & $1.01 \pm 0.17^{\star \star \star}$ & $849 \pm 624 \mathrm{NS}$ & 39 \\
Wheat-pulse & 0.80 & $1.09 \pm 0.09^{\star \star *}$ & $927 \pm 380^{\star}$ & 40 \\
\hline
\end{tabular}

${ }^{*},{ }^{* *},{ }^{* * *}$, indicates significance at a $p<0.05,0.01$, and 0.001 level. NS, Not significant.

TABLE 4 | Regression parameters for the linear relationship between winter wheat yield following other cereals, oilseeds, or pulses and wheat following fallow.

\begin{tabular}{lcccc}
\hline & $\boldsymbol{R}^{\mathbf{2}}$ & Slope & Intercept & $\boldsymbol{n}$ \\
\hline LITERATURE SURVEY & & & \\
Wheat-cereal & 0.76 & $0.77 \pm 0.04^{\star \star \star}$ & $-332 \pm 131^{\star \star}$ & 99 \\
Wheat-oilseed & 0.89 & $1.10 \pm 0.05^{\star \star *}$ & $-593 \pm 174^{\star \star}$ & 69 \\
Wheat-pulse & 0.75 & $0.97 \pm 0.05^{\star \star \star}$ & $-325 \pm 126 \mathrm{NS}$ & 138 \\
PNW & & & & \\
Wheat-cereal & 0.98 & $0.79 \pm 0.06^{\star \star \star}$ & $-695 \pm 247 \mathrm{NS}$ & 12 \\
Wheat-oilseed & 0.73 & $0.87 \pm 0.17^{\star \star \star}$ & $-109 \pm 840 \mathrm{NS}$ & 5 \\
Wheat-pulse & 0.66 & $0.80 \pm 0.33 \mathrm{NS}$ & $-475 \pm 1,302 \mathrm{NS}$ & 5 \\
\hline
\end{tabular}

**, ${ }^{* * *}$, indicates significance at a $p<0.01,0.001$ level. NS, Not significant. in place of fallow, and $325 \mathrm{~kg} \mathrm{ha}^{-1}$ following pulses (as indicated by the negative $y$-intercepts and regression slopes of $0.97-1.10$, Table 4).

These trends illustrate that break crops could not replace fallow without penalizing WW yields in the iPNW, unlike effects reported elsewhere. These results may be attributed to systematic differences between the iPNW and other regions, such as the Northern Great Plains. Despite similarities in soils and water holding capacity, the Great Plains is characterized by summerdominated rainfall (Pan et al., 2016b). Spring crops dominate in the Northern Great Plains, whereas WW is predominant in the iPNW due to its winter-dominant precipitation patterns, moderate winter temperatures, and drought and heat stress frequently encountered during the flowering and grain-fill period with spring crops. In the iPNW, WW yields greatly exceed those for SW, due to their more efficient utilization of winter precipitation and earlier grain filling (Schillinger et al., 2008). Together, these conditions make WW production more economic but also highly reliant on stored precipitation for both crop establishment and in-season growth. While our study indicated that conservation tillage practices have benefits compared to traditional tillage on WW yields at lower yield potentials, chemical fallow may not provide advantages observed in the Northern Great Plains. In particular, chemical fallow does not provide gains in soil water storage efficiency (Schillinger and Bolton, 1993) over conservation-tillage fallow. Nevertheless, chemical fallow has been reported to be, overall, just as efficient as tilled fallow in retaining soil moisture throughout the 13 month fallow period in areas receiving more than $290 \mathrm{~mm}$ annual precipitation (Schillinger, unpublished; Machado et al., 2015). Previous research in the region has also demonstrated that conservation practices can be more profitable if weeds are properly managed, and conservation production systems may incorporate multi-faceted approaches to manage weeds in the low precipitation zone (Young, 2004).

Importantly, we found that the timing and frequency of fallow was an important consideration for the region. In particular, a reduction of fallow frequency could be practiced under lowprecipitation conditions without penalizing WW yields as long as fallow preceded WW. Our results also support previous results at individual sites in Moro, OR (Machado et al., 2015) and Lind, WA (Schillinger, 2016), who determined that intensified rotations were agronomically competitive to a traditional WWfallow rotation which practiced fallow every 3 years but prior to WW.

\section{Cropping System Productivity in Continuous Cropping}

Despite the yield penalty on WW in continuous cropping systems under low precipitation conditions, continuous cropping may be agronomically feasible on an annualized basis of whole rotations. From 2012 to 2014/2015, intensification of cropping systems through the reduction of fallow frequency or elimination of fallow periods did not affect annualized energy outputs or grain $\mathrm{N}$ export (Figure 7), though more intensified systems received more fertilizer inputs at Moro, 
TABLE 5 | Rotational fertilizer and total N balance for Moro, Ritzville, and Davenport from 2012 to 2014.

\begin{tabular}{|c|c|c|c|c|c|c|c|c|c|}
\hline & $\begin{array}{l}\text { 1. Initial soil } \\
\text { inorganic N }\end{array}$ & $\begin{array}{l}\text { 2. Total } \mathbf{N} \\
\text { mineralization }\end{array}$ & $\begin{array}{l}\text { 3. Total fertilizer } \\
\mathrm{N} \text { inputs }\end{array}$ & $\begin{array}{l}\text { 4. Total } \\
\text { grain } \mathbf{N}\end{array}$ & $\begin{array}{l}\text { 5. Final soil } \\
\text { inorganic } N\end{array}$ & $\begin{array}{c}\text { Total } \\
\text { inputs }\end{array}$ & $\begin{array}{c}\text { Total } \\
\text { outputs }\end{array}$ & $\begin{array}{c}\text { Fertilizer } \mathbf{N} \\
\text { balance }\end{array}$ & $\begin{array}{l}\text { Rotational N } \\
\text { balance }\end{array}$ \\
\hline & & & kg N ha ${ }^{-1}$ & & & $1+2+3$ & $4+5$ & $3-4$ & $(1+2+3)-(4+5)$ \\
\hline \multicolumn{10}{|l|}{ MORO, OR } \\
\hline ww-sf & 66 & 59 & 95 & 154 & 92 & 220 & 246 & -59 & -26 \\
\hline ww-cf & 58 & 78 & 75 & 173 & 96 & 211 & 269 & -98 & -58 \\
\hline ww-sb-cf & 76 & 62 & 129 & 157 & 84 & 266 & 241 & -29 & 25 \\
\hline sw-sw & 53 & 59 & 111 & 144 & 80 & 223 & 224 & -33 & -1 \\
\hline sb-sb & 45 & 55 & 166 & 167 & 116 & 266 & 283 & -1 & -17 \\
\hline$w w-w w$ & 9 & 73 & 148 & 151 & 53 & 230 & 204 & -3 & 26 \\
\hline \multicolumn{10}{|c|}{ RITZVILLE, WA } \\
\hline ww-tf & 156 & 65 & 98 & 166 & 54 & 319 & 220 & -68 & 100 \\
\hline ww-sw-tf & 20 & 73 & 129 & 148 & 30 & 221 & 178 & -19 & 43 \\
\hline trit-sw-cf & 16 & 73 & 101 & 137 & 60 & 190 & 197 & -36 & -7 \\
\hline sw-sw & 18 & 79 & 135 & 143 & 57 & 231 & 199 & -8 & 32 \\
\hline sw-sb & 18 & 83 & 135 & 149 & 42 & 236 & 191 & -14 & 45 \\
\hline \multicolumn{10}{|c|}{ DAVENPORT, WA } \\
\hline cf-ww-sw & 85 & 110 & 155 & 146 & 139 & 350 & 284 & 10 & 66 \\
\hline cf-ww-can & 85 & 110 & 139 & 158 & 74 & 333 & 232 & -19 & 101 \\
\hline sw-ww-sw & 85 & 110 & 232 & 184 & 86 & 427 & 270 & 48 & 157 \\
\hline can-ww-sw & 85 & 110 & 215 & 194 & 138 & 410 & 332 & 21 & 78 \\
\hline cam-ww-sw & 85 & 110 & 215 & 179 & 151 & 410 & 330 & 37 & 80 \\
\hline
\end{tabular}

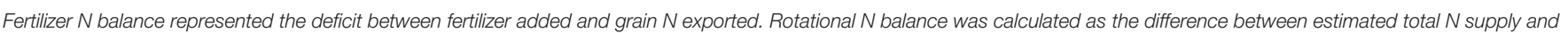

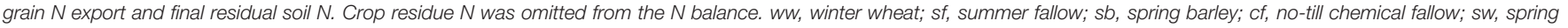
wheat; trit, winter tricticale; can, spring canola; cam, spring camelina.

OR, Ritzville, WA, and Davenport, WA. Alternative cropping systems also did not differ significantly in rotational fertilizer use efficiency patterns from traditional rotations. In particularly, the relationship between fertilizer $\mathrm{N}$ and annualized energy production (Figure 8A) and grain $\mathrm{N}$ accumulation (Figure $\mathbf{8 C}$ ) did not differ whether wheat followed fallow or crops when annual precipitation was $<350 \mathrm{~mm} \mathrm{yr}^{-1}$. Nitrogen fertilization increased energy yields and grain $\mathrm{N}$ accumulation, but explained only $13 \%$ of the variation in energy outputs (Figure $\mathbf{8 A}$ ) and $21 \%$ of grain $\mathrm{N}$ accumulation (Figure $8 \mathrm{C}$ ) in traditional systems. In comparison, $17 \%$ of energy outputs and $25 \%$ of grain $\mathrm{N}$ variability were explained by $\mathrm{N}$ fertilization rates in alternative rotations with the reduction or elimination of fallow. Like WW, plant $\mathrm{N}$ was tightly regulated to produce grain (Figure 8B) and synthesis grain protein (Figure 8D) across all data, explaining 82-97\%. Importantly, no differences among relationships were observed due to reduction or elimination of fallow when annual precipitation was $<350 \mathrm{~mm} \mathrm{yr}^{-1}$.

Researchers in other Mediterranean climates have also reported agronomically viable intensified rotations, despite lower wheat yields upon the elimination of fallow (Christiansen et al., 2015). Cropping systems research in Canada have indicated that intensified rotations were agronomically feasible (Zentner et al., 2003), and fallow timing (e.g., wheat following fallow or recrop) predominately influenced annual wheat productivity in intensified rotations even though annualized grain yields increased with cropping intensity (Campbell et al., 2004).
Continuous cropping of wheat rotated with legumes reduced the fertilizer requirements of a wheat-fallow rotation, and economics were dependent on commodity prices (Zentner et al., 2001). However, despite greater economic returns, financial risk increased with continuous wheat (Zentner et al., 2006).

In the iPNW, research has indicated that continuous spring cropping may be agronomically feasible (Schillinger et al., 2007; Bewick et al., 2008), even with less precipitation than we observed in our study (Machado et al., 2015). However, in six cropping seasons previously conducted at Ralston, the wheat-fallow system yielded 25\% more than continuous spring wheat (Young et al., 2015). Furthermore, observations taken from a only few years, such as in the present study, may not be consistent over decades (Nielsen and Vigil, 2014). Previous research has also found that the profitability diminishes relative to $\mathrm{WW}$-fallow rotations in the low precipitation zone due to high year-to-year yield variability and associated economic risk (Juergens et al., 2004; Schillinger and Young, 2004; Schillinger et al., 2007; Bewick et al., 2008). This finding may be due to differential pricing of alternative spring crops, increased costs associated with $\mathrm{N}$ fertilizers, changes in weed pressure (Sullivan et al., 2013), and grain yields in continuous cropping systems that average only $50-60 \%$ of WW following fallow.

Lastly, we developed $\mathrm{N}$ budgets at Moro, Ritzville, and Davenport to determine the effect of crop intensification in fertilizer $\mathrm{N}$ balances and unaccounted for $\mathrm{N}$ over multiple years (Table 5). At all locations, the fertilizer $\mathrm{N}$ balance was 
greater (fertilizer $\mathrm{N}$ exceeded grain $\mathrm{N}$ ) for all continuous cropping systems with spring wheat, barley, camelina, or canola implementing conservation practices than the traditional fallow rotations. However, the total $\mathrm{N}$ balance had no discernible trends according to intensification. Earlier examination of $\mathrm{N}$ fertilizer balances at the Ralston site also revealed that the WW-summer fallow conventional system, when fertilized during the fallow period, had the highest fertilizer $\mathrm{N}$ efficiency (grain $\mathrm{N} /$ fertilizer $N=76.8 \%)$ compared to spring wheat-chemical fallow (64\%), due to deeper rooting and efficient soil $\mathrm{N}$ extraction by winter wheat down to $150 \mathrm{~cm}$ (Pan et al., 2001). Similar to the latter rotation, continuous no-till spring cereal cropping also had a lower fertilizer $\mathrm{N}$ efficiency (grain $\mathrm{N} /$ fertilizer $N=61.7 \%$ ) and water extraction, as evidenced by nitrate movement below 90 $\mathrm{cm}$. It is notable that although conventional $\mathrm{WW}$ is fertilized during fallow nearly a year before the accelerated $\mathrm{N}$ uptake phase of winter wheat, the grain $\mathrm{N}$ to fertilizer index is surprisingly high in this low rainfall zone. While mineralized $\mathrm{N}$ accumulates during the fallow period in addition to the fertilizer application, soil tests indicate minimal overwinter nitrate leaching beyond the $150 \mathrm{~cm}$ root profile. The pre-plant $\mathrm{N}$ application during fallow allows growers to spread their workloads, and for the ammonia to nitrify and move into the middle of the winter wheat root zone, at $60-90 \mathrm{~cm}$ soil depths. Similarly, high $\mathrm{N}$ fertilizer efficiencies of WW-summer fallow grown in the northern iPNW near Okanogan, WA, has been observed, with $79 \%$ of fallowapplied ammonia over 20 years accounted for in harvested grain, and the remainder was accountable in an increase in soil organic $\mathrm{N}$ over that period (Pan et al., in review). This fertilizer $\mathrm{N}$ recovery was higher than the biosolids $\mathrm{N}$ recovery $(24-37 \%)$ WW-summer fallow, when biosolids were applied once every 4 years at 3 different rates. However, biosolids significantly made greater contributions to the build-up of soil organic $\mathrm{N}$, leading to the conclusion that while the synthetic fertilizer mainly fed the wheat grain, the biosolids fed both the wheat grain and the soil organic matter build-up. Nevertheless, the biosolids applications resulted in more net unaccounted for $\mathrm{N}$ than the ammonia.

\section{CONCLUSION}

Our region-wide assessment examined the performance of WW across the regional precipitation gradient. We observed that WW yields increased with increasing annual precipitation before maximizing at $520 \mathrm{~mm} \mathrm{yr}^{-1}$ and subsequently declining. While fallow periods were effective at mitigating low $\mathrm{N}$ fertilization efficiencies under low precipitation, fertilization efficiencies decreased as annual precipitation exceeded $500 \mathrm{~mm} \mathrm{yr}^{-1}$.

\section{REFERENCES}

Abalos, D., Jeffery, S., Sanz-Cobena, A., Guardia, G., and Vallejo, A. (2014). Meta-analysis of the effect of urease and nitrification inhibitors on crop productivity and nitrogen use efficiency. Agric. Ecosyst. Environ. 189, 136-144. doi: 10.1016/j.agee.2014. 03.036
Reduction in WW yields in the highest precipitation zones were partially explained by decline in the overall soil water holding capacity in the argillic and fragipan soils in this region. We also observed considerable between-site and within-site variability in WW yields in response to annual precipitation and $\mathrm{N}$ fertilization. These results indicate that other soil, climatic, and management factors other than annual precipitation and fertilizer $\mathrm{N}$ rate have a large influence on WW yields. These results provide a rationale that precision $\mathrm{N}$ management is needed across the region and not limited to regions with risks of leaching or denitrification losses or areas with high topographic complexity.

Although, WW yields seem to increase following pulses and oilseeds rather than spring wheat across a range of yield potentials and when under conservation tillage practices at low yield potential sites, WW yields declined when following crops rather than fallow when annual precipitation was $<350$ $\mathrm{mm} \mathrm{yr}^{-1}$. The variance in $\mathrm{WW}$ yields also increased in alternative rotations. Nevertheless, WW yields were not affected when the frequency of fallow was reduced to once every 3 years, as long as fallow preceded the WW. Despite the yield penalty associated with eliminating fallow prior to $\mathrm{WW}$, cropping system level productivity under the low annual precipitation $\left(<350 \mathrm{~mm} \mathrm{yr}^{-1}\right.$ ) was not affected by intensification, diversification, or conservation tillage. Nevertheless, multiyear $\mathrm{N}$ balances did not reveal any consistent benefit of intensified and diversified cropping in reducing unaccounted for $\mathrm{N}$, whereas fertilizer $\mathrm{N}$ balance (fertilizer $\mathrm{N}>$ grain $\mathrm{N}$ ) increased with intensification. Therefore, increased fertilizer $\mathrm{N}$ inputs and lower fertilizer efficiencies may offset and limit the economic feasibility of intensified and diversified cropping systems.

\section{AUTHOR CONTRIBUTIONS}

WP conceptualized, initiated, and organized the study; TM drafted the manuscript and performed data analyses; WS, SM, EB, FY, and JJ provided data, proposed analytical analyses, conceptualized individual site research, revised the manuscript; LY, IL, AG, IM collected, managed, and provided data and site information; AE, HC helped organize the study and managed individual site research.

\section{FUNDING}

This research was funded through Award \#2011-68002-30191 from USDA National Institute for Food and Agriculture. Pacific Northwest.

Alam, M. M., Ladha, J. K., Faisal, M. W., Sharma, S., Saha, A., Noor, S., et al. (2015). Improvement of cereal-based cropping systems following the principles of conservation agriculture under changing agricultural scenarios in Bangladesh. Field Crops Res. 175, 1-15. doi: 10.1016/j.fcr.2014.12.015 
Altieri, M. A., Nicholls, C. I., Henao, A., and Lana, M. A. (2015). Agroecology and the design of climate change-resilient farming systems. Agron. Sustain. Dev. 35, 869-890. doi: 10.1007/s13593-015-0285-2

Anderson, R. L., Tanaka, D. L., and Merrill, S. D. (2003). Yield and water use of broadleaf crops in a semiarid climate. Agric. Water Manage. 58, 255-266. doi: 10.1016/S0378-3774(02)00085-9

Angadi, S., McConkey, B. G., Cutforth, H. W., Miller, P. R., Ulrich, D., Selles, F., et al. (2008). Adaptation of alternative pulse and oilseed crops to the semiarid Canadian Prairie: seed yield and water use efficiency. Can. J. Plant Sci. 88, 425-438. doi: 10.4141/CJPS07078

Angus, J. F., Kirkegaard, J. A., Hunt, J. R., Ryan, M. H., Ohlander, L., and Peoples, M. B. (2015). Break crops and rotations for wheat. Crop Pasture Sci. 66, 523-552. doi: 10.1071/CP14252

Asseng, S., Ewert, F., Martre, P., Rötter, R. P., Lobell, D. B., Cammarano, D., et al. (2015). Rising temperatures reduce global wheat production. Nat. Clim. Change 5, 143-147. doi: $10.1038 /$ nclimate 2470

Babu, S., Singh, R., Avasthe, R. K., Yadav, G. S., and Rajkhowa, D. J. (2016). Intensification of maize (Zea mays) -based cropping sequence in rainfed ecosystem of Sikkim Himalayas for improving system productivity, profitability, employment generation and energy-use efficiency under organic management condition. Indian J. Agric. Sci. 86, 778-784. Available online at: http://epubs.icar.org.in/ejournal/index.php/IJAgS/article/view/58980

Bewick, L. S., Young, F. L., Alldredge, J. R., and Young, D. L. (2008). Agronomics and economics of no-till facultative wheat in the Pacific Northwest, USA. Crop Prot. 27, 932-942. doi: 10.1016/j.cropro.2007.11.013

Bolton, F. E., and Glenn, D. M. (1983). Fallow-Cropping Systems in the Pacific Northwest. Corvallis, OR: Oregon State University Agriculture Experiment Station.

Brandt, S. A., and Zentner, R. P. (1995). Crop production under alternate rotations on a Dark Brown Chernozemic soil at Scott, Saskatchewan. Can. J. Plant Sci. 75, 789-794. doi: 10.4141/cjps95-133

Bremer, E., Janzen, H. H., Ellert, B. H., and McKenzie, R. H. (2011). Carbon, nitrogen, and greenhouse gas balances in an 18-Year cropping system study on the Northern Great Plains. Soil Sci. Soc. Am. J. 75, 1493-1502. doi: $10.2136 /$ sssaj2010.0326

Brooks, E. S., Boll, J., and McDaniel, P. A. (2012). “Chapter 10 - Hydropedology in seasonally dry landscapes: the Palouse region of the Pacific Northwest USA," in Hydropedology, ed H. Lin (Boston, MA: Academic Press), 329-350.

Brooks, E. S., Boll, J., Snyder, A. J., Ostrowski, K. M., Kane, S. L., Wulfhorst, J. D., et al. (2010). Long-term sediment loading trends in the Paradise Creek watershed. J. Soil Water Conserv. 65, 331-341. doi: 10.2489/jswc.65.6.331

Brown, T., Huggins, D. R., and Kruger, C. (2015). Performance Criteria for Evaluating Site-Specific Nitrogen Management. Regional Approaches to Climate Change for Pacific Northwest.

Bueckert, R. A., and Clarke, J. M. (2013). Review: annual crop adaptation to abiotic stress on the Canadian prairies: six case studies. Can. J. Plant Sci. 93, 375-385. doi: 10.4141/cjps2012-184

Burney, J. A., Davis, S. J., and Lobell, D. B. (2010). Greenhouse gas mitigation by agricultural intensification. Proc. Natl. Acad. Sci. U.S.A. 107, 12052-12057. doi: 10.1073/pnas.0914216107

Campbell, C. A., Lafond, G. P., VandenBygaart, A. J., Zentner, R. P., Lemke, R., May, W. E., et al. (2011). Effect of crop rotation, fertilizer and tillage management on spring wheat grain yield and $\mathrm{N}$ and $\mathrm{P}$ content in a thin Black Chernozem: a long-term study. Can. J. Plant Sci. 91, 467-483. doi: $10.4141 /$ cjps10032

Campbell, C. A., Zentner, R. P., Selles, F., Biederbeck, V. O., McConkey, B. G., Lemke, R., et al. (2004). Cropping frequency effects on yield of grain, straw, plant $\mathrm{N}, \mathrm{N}$ balance and annual production of spring wheat in the semiarid prairie. Can. J. Plant Sci. 84, 487-501. doi: 10.4141/ P03-078

Chen, C., Neill, K., Burgess, M., and Bekkerman, A. (2012). Agronomic benefit and economic potential of introducing fall-seeded pea and lentil into conventional wheat-based crop rotations. Agron. J. 104, 215-224. doi: 10.2134/agronj2011.0126

Christiansen, S., Ryan, J., Singh, M., Ates, S., Bahhady, F., Mohamed, K., et al. (2015). Potential legume alternatives to fallow and wheat monoculture for Mediterranean environments. Crop Pasture Sci. 66, 113-121. doi: 10.1071/CP14063

Conley, S. P., Bordovsky, D., Rife, C., and Wiebold, W. J. (2004). Winter canola survival and yield response to nitrogen and fall phosphorus. CM 3 . doi: 10.1094/CM-2004-0901-01-RS

Cook, R. J. (1986). Wheat management systems in the Pacific Northwest. Plant Dis. 70:894. doi: 10.1094/PD-70-894

Cook, R. J., Schillinger, W. F., and Christensen, N. W. (2002). Rhizoctonia root rot and take-all of wheat in diverse direct-seed spring cropping systems. Can. J. Plant Pathol. 24, 349-358. doi: 10.1080/07060660209507020

Cutforth, H. W., Angadi, S. V., McConkey, B. G., Entz, M. H., Ulrich, D., Volkmar, K. M., et al. (2009). Comparing plant water relations for wheat with alternative pulse and oilseed crops grown in the semiarid Canadian prairie. Can. J. Plant Sci. 89, 823-835. doi: 10.4141/CJPS08138

Cutforth, H. W., Angadi, S. V., McConkey, B. G., Miller, P. R., Ulrich, D., Gulden, R., et al. (2013). Comparing rooting characteristics and soil water withdrawal patterns of wheat with alternative oilseed and pulse crops grown in the semiarid Canadian prairie. Can. J. Soil Sci. 93, 147-160. doi: 10.4141/cjss2012-081

Davis, A. S., Hill, J. D., Chase, C. A., Johanns, A. M., and Liebman, M. (2012). Increasing cropping system diversity balances productivity, profitability and environmental health. PLoS ONE 7:e47149. doi: 10.1371/journal.pone.0047149

Entz, M. H., Baron, V. S., Carr, P. M., Meyer, D. W., Smith, S. R., and McCaughey, W. P. (2002). Potential of forages to diversify cropping systems in the northern Great Plains. Agron. J. 94, 240-250. doi: 10.2134/agronj2002.0240

Erda, L., Wei, X., Hui, J., Yinlong, X., Yue, L., Liping, B., et al. (2005). Climate change impacts on crop yield and quality with $\mathrm{CO}_{2}$ fertilization in China. Philos. Trans. R. Soc. B Biol. Sci. 360, 2149-2154. doi: 10.1098/rstb.2005.1743

Farine, D. R., O'Connell, D. A., Grant, T., and Poole, M. L. (2010). Opportunities for energy efficiency and biofuel production in Australian wheat farming systems. Biofuels 1, 547-561. doi: 10.4155/bfs.10.29

Felton, W. L., Marcellos, H., Alston, C., Martin, R. J., Backhouse, D., Burgess, L. W., et al. (1998). Chickpea in wheat-based cropping systems of northern New South Wales. II. Influence on biomass, grain yield, and crown rot in the following wheat crop. Aust. J. Agric. Res. 49, 401-408. doi: 10.1071/A97067

Feng, G., Sharratt, B., and Young, F. (2011). Soil properties governing soil erosion affected by cropping systems in the U.S. Pacific Northwest. Soil Tillage Res. 111, 168-174. doi: 10.1016/j.still.2010.09.008

Fiez, T. E., Miller, B. C., and Pan, W. L. (1994). Winter wheat yield and grain protein across varied landscape positions. Agron. J. 86, 1026 doi: 10.2134/agronj1994.00021962008600060018x

Fiez, T. E., Pan, W. L., and Miller, B. C. (1995). Nitrogen use efficiency of winter wheat among landscape positions. Soil Sci. Soc. Am. J. 59, 1666-1671. doi: 10.2136/sssaj1995.03615995005900060023x

Gan, Y., Campbell, C. A., Liu, L., Basnyat, P., and McDonald, C. L. (2009). Water use and distribution profile under pulse and oilseed crops in semiarid northern high latitude areas. Agric. Water Manag. 96, 337-348. doi: 10.1016/j.agwat.2008.08.012

Gan, Y., Hamel, C., O’Donovan, J. T., Cutforth, H., Zentner, R. P., Campbell, C. A., et al. (2015). Diversifying crop rotations with pulses enhances system productivity. Sci. Rep. 5:14625. doi: 10.1038/srep14625

Gan, Y., Liang, C., Wang, X., and McConkey, B. (2011). Lowering carbon footprint of durum wheat by diversifying cropping systems. Field Crops Res. 122, 199-206. doi: 10.1016/j.fcr.2011.03.020

Gardner, P. A., Angus, J. F., Wong, P. T. W., Pitson, G. D., Gardner, P. A., Angus, J. F., et al. (1998). A comparison of six methods to control take-all in wheat. Crop Pasture Sci. 49, 1225-1240. doi: 10.1071/A98050

Garrido, R. J. L.-B., and López-Bellido, L. (2001). Effects of crop rotation and nitrogen fertilization on soil nitrate and wheat yield under rainfed Mediterranean conditions. Agronomie 21, 509-516. doi: 10.1051/agro: 2001140

Gizaw, S. A., Garland-Campbell, K., and Carter, A. H. (2016). Evaluation of agronomic traits and spectral reflectance in Pacific Northwest winter wheat under rain-fed and irrigated conditions. Field Crops Res. 196, 168-179. doi: 10.1016/j.fcr.2016.06.018

Gregory, P. J., and Gregory, P. J. (1997). Alternative crops for duplex soils: growth and water use of some cereal, legume, and oilseed crops, and pastures. Crop Pasture Sci. 49, 21-32. 
Guo, R., Lin, Z., Mo, X., and Yang, C. (2010). Responses of crop yield and water use efficiency to climate change in the North China Plain. Agric. Water Manag. 97, 1185-1194. doi: 10.1016/j.agwat.2009.07.006

Guy, S. O. (2013). Rotational Influence of Brassica Biofuel and Other Crops on Winter Wheat. Washington State University. Available online at: http://css.wsu.edu/biofuels/reports/

Halvorson, A. D., Black, A. L., Krupinsky, J. M., Merrill, S. D., and Tanaka, D. L. (1999). Sunflower response to tillage and nitrogen fertilization under intensive cropping in a wheat rotation. Agron. J. 91, 637-642. doi: 10.2134/agronj1999. 914637x

Hammel, J. (1995). Long-term tillage and crop-rotation effects on winterwheat production. Agron. J. 87, 16-22. doi: 10.2134/agronj1995. 00021962008700010004x

Hansen, N. C., Allen, B. L., Baumhardt, R. L., and Lyon, D. J. (2012). Research achievements and adoption of no-till, dryland cropping in the semi-arid U.S. Great Plains. Field Crops Res. 132, 196-203. doi: 10.1016/j.fcr.2012.02.021

Holford, I. C. R., Crocker, G. J., Holford, I. C. R., and Crocker, G. J. (1997). A comparison of chickpeas and pasture legumes for sustaining yields and nitrogen status of subsequent wheat. Crop Pasture Sci. 48, 305-316. doi: 10.1071/A96072

Horner, G. M., Starr, W. A., and Patterson, J. K. (1957). "The Pacific Northwest wheat region," in The Yearbook of Agriculture (Washington, DC: US Department of Agriculture), 475-481.

Johnson-Maynard, J. L., Umiker, K. J., and Guy, S. O. (2007). Earthworm dynamics and soil physical properties in the first three years of no-till management. Soil Tillage Res. 94, 338-345. doi: 10.1016/j.still.2006.08.011

Johnston, A. M., Kutcher, H. R., and Bailey, K. L. (2005). Impact of crop sequence decisions in the Saskatchewan Parkland. Can. J. Plant Sci. 85, 95-102. doi: 10.4141/P04-090

Juergens, L. A., Young, D. L., Schillinger, W. F., and Hinman, H. R. (2004). Economics of alternative no-till spring crop rotations in Washington's wheatfallow region. Agron. J. 96, 154-158. doi: 10.2134/agronj2004.0154

Keshavarz-Afshar, R., and Chen, C. (2015). Intensification of dryland cropping systems for bio-feedstock production: energy analysis of camelina. Bioenergy Res. 8, 1877-1884. doi: 10.1007/s12155-015-9644-8

Kirkegaard, J., Christen, O., Krupinsky, J., and Layzell, D. (2008). Break crop benefits in temperate wheat production. Field Crops Res. 107, 185-195. doi: 10.1016/j.fcr.2008.02.010

Kirkegaard, J. A., and Hunt, J. R. (2010). Increasing productivity by matching farming system management and genotype in water-limited environments. J. Exp. Bot. 61, 4129-4143. doi: 10.1093/jxb/erq245

Kirkegaard, J. A., Sarwar, M., Wong, P. T. W., and Newell, M. (2000). Field studies on the biofumigation of take-all by Brassica break crops. Crop Pasture Sci. 51, 445-456. doi: 10.1071/AR99106

Kirkegaard, J. A., Simpfendorfer, S., Holland, J., Bambach, R., Moore, K. J., and Rebetzke, G. J. (2004). Effect of previous crops on crown rot and yield of durum and bread wheat in northern NSW. Aust. J. Agric. Res. 55, 321-334. doi: 10.1071/AR03178

Kollmorgen, J. F., Griffiths, J. B., and Walsgott, D. N. (1983). The effects of various crops on the survival and carry-over of the wheat take-all fungus Gaeumannomyces graminis var. tritici. Plant Pathol. 32, 73-77. doi: 10.1111/j.1365-3059.1983.tb01303.x

Koocheki, A., Nassiri, M., Gliessman, S. R., and Zarea, A. (2008). Agrobiodiversity of field crops: a case study for Iran. J. Sustain. Agric. 32, 95-122. doi: 10.1080/10440040802121445

Kunkel, K. E., Palecki, M., Ensor, L., Hubbard, K. G., Robinson, D., Redmond, K., et al. (2009). Trends in twentieth-century U.S. snowfall using a quality-controlled dataset. J. Atmos. Ocean. Technol. 26, 33-44. doi: 10.1175/2008JTECHA1138.1

Lafond, G. P., Loeppky, H., and Derksen, D. A. (1992). The effects of tillage systems and crop rotations on soil water conservation, seedling establishment and crop yield. Can. J. Plant Sci. 72, 103-115. doi: 10.4141/cjps92-011

Leggett, G. E., Ramig, R. E., Johnson, L. C., and Masse, T. W. (1974). Summer Fallow in the Northwest. Washington, DC: ARS-USDA.

Lenssen, A. W., Waddell, J. T., Johnson, G. D., and Carlson, G. R. (2007). Diversified cropping systems in semiarid Montana: nitrogen use during drought. Soil Tillage Res. 94, 362-375. doi: 10.1016/j.still.2006. 08.012
Lin, B. B. (2011). Resilience in agriculture through crop diversification: adaptive management for environmental change. Bioscience 61, 183-193. doi: 10.1525/bio.2011.61.3.4

López-Bellido, L., López-Bellido, R. J., Castillo, J. E., and López-Bellido, F. J. (2000). Effects of tillage, crop rotation, and nitrogen fertilization on wheat under rainfed mediterranean conditions. Agron. J. 92, 1054-1063. doi: 10.2134 /agronj2000.9261054x

Maaz, T., Wulfhorst, J. D., McCracken, V., Kirkegaard, J. A., Huggins, D. R., Roth, I., et al. (in press). Economic, policy, and social trends and challenges of introducing oilseed and pulse crops into dryland wheat cropping systems. Agric. Ecosyst. Environ. doi: 10.1016/j.agee.2017.03.018

Machado, S., Pritchett, L., and Petrie, S. (2015). No-tillage cropping systems can replace traditional summer fallow in North-Central Oregon. Agron. J. 107, 1863-1877. doi: 10.2134/agronj14.0511

Magney, T. S., Eitel, J. U. H., Huggins, D. R., and Vierling, L. A. (2016a). Proximal NDVI derived phenology improves in-season predictions of wheat quantity and quality. Agric. For. Meteorol. 217, 46-60. doi: 10.1016/j.agrformet.2015.11.009

Magney, T. S., Eitel, J. U. H., and Vierling, L. A. (2016b). Mapping wheat nitrogen uptake from RapidEye vegetation indices. Precis. Agric. 1-23. doi: 10.1007/s11119-016-9463-8

Mahler, R. L. (2007). Winter Wheat Northern Idaho Fertilizer Guide. Moscow, ID: University of Idaho Extension.

Mahler, R. L., Wilson, S., and Shafii, B. (2014). The adoption of new technologies in dryland farming regions of Idaho, Washington, and Oregon. Nat. Sci. Educ. 43, 102-108. doi: 10.4195/nse2013.03.0006

Malik, R. S., Seymour, M., French, R. J., Kirkegaard, J. A., Lawes, R. A., and Liebig, M. A. (2015). Dynamic crop sequencing in Western Australian cropping systems. Crop Pasture Sci. 66, 594-609. doi: 10.1071/CP14097

Matson, P. A., Parton, W. J., Power, A. G., and Swift, M. J. (1997). Agricultural Intensification and Ecosystem Properties. Science 277, 504-509. doi: $10.1126 /$ science.277.5325.504

McDaniel, P. A., Gabehart, R. W., Falen, A. L., Hammel, J. E., and Reuter, R. J. (2001). Perched water tables on argixeroll and fragixeralf hillslopes. Soil Sci. Soc. Am. J. 65, 805-810. doi: 10.2136/sssaj2001.653805x

McGrath, J. M., and Lobell, D. B. (2013). Regional disparities in the $\mathrm{CO}_{2}$ fertilization effect and implications for crop yields. Environ. Res. Lett. 8:014054. doi: 10.1088/1748-9326/8/1/014054

McVicar, R., Slinkard, A. E., Vandenberg, A., and Clancey, B. (2000). "Trends in pulse crop diversification in western Canada and effects on world trade," in Linking Research and Marketing Opportunities for Pulses in the 21st Century Current Plant Science and Biotechnology in Agriculture, ed R. Knight (Springer Netherlands), 243-249.

Miao, Y., Stewart, B. A., and Zhang, F. (2011). Long-term experiments for sustainable nutrient management in China. A review. Agron. Sustain. Dev. 31, 397-414. doi: 10.1051/agro/2010034

Miller, P. R., Gan, Y., McConkey, B. G., and McDonald, C. L. (2003). Pulse crops for the northern Great Plains: II. Cropping sequence effects on cereal, oilseed, and pulse crops. Agron. J. 95, 980-986. doi: 10.2134/agronj2003.0980

Miller, P. R., and Holmes, J. A. (2005). Cropping sequence effects of four broadleaf crops on four cereal crops in the Northern Great Plains. Agron. J. 97, 189-200. doi: 10.2134/agronj2005.0189

Morrow, J. G., Huggins, D. R., and Reganold, J. P. (2017). Climate change predicted to negatively influence surface soil organic matter of dryland cropping systems in the Inland Pacific Northwest, USA. Front. Ecol. Evol. 5:10. doi: $10.3389 /$ fevo.2017.00010

Mote, P. W., Snover, A. K., Capalbo, S., Eigenbrode, S., Glick, P., Littel, J., et al. (2014). "Northwest," in Climate Change Impacts in the United States: The Third National Climate Assessment (U.S. Global Change Research Program), 487-513. Available online at: http://nca2014.globalchange.gov/downloads (Accessed January 31, 2017).

Mousavi-Avval, S. H., Rafiee, S., Jafari, A., and Mohammadi, A. (2011). Energy flow modeling and sensitivity analysis of inputs for canola production in Iran. J. Clean. Prod. 19, 1464-1470. doi: 10.1016/j.jclepro.2011. 04.013

Mulla, D. J., Bhatti, A. U., Hammond, M. W., and Benson, J. A. (1992). A comparison of winter wheat yield and quality under uniform versus spatially variable fertilizer management. Agric. Ecosyst. Environ. 38, 301-311. doi: 10.1016/0167-8809(92)90152-2 
Nielsen, D. C., and Vigil, M. F. (2014). Searching for synergism in dryland cropping systems in the central Great Plains. Field Crops Res. 158, 34-42. doi: $10.1016 /$ j.fcr.2013.12.020

Owen, K. J., Clewett, T. G., and Thompson, J. P. (2010). Pre-cropping with canola decreased Pratylenchus thornei populations, arbuscular mycorrhizal fungi, and yield of wheat. Crop Pasture Sci. 61, 399-410. doi: 10.1071/CP09345

Pan, W. L., McClellan Maaz, T., Hammac, W. A., McCracken, V. A., and Koenig, R. T. (2016a). Mitscherlich-modeled, semi-arid Canola nitrogen requirements influenced by soil nitrogen and water. Agron. J. 108, 884-894. doi: 10.2134/agronj2015.0378

Pan, W. L., Schillinger, W., Huggins, D. R., Koenig, R., and Burns, J. (2007). "Fifty years of predicting wheat nitrogen requirements based on soil water, yield, protein, and nitrogen efficiencies," in Proceedings of the Soil Science Society of America Symposium Integrating Weather Variability into Nitrogen Recommendations (Indianapolis, IN).

Pan, W. L., Young, F., and Kidwell, K. K. (2001). "Carbon and nitrogen cycling in direct-seeded spring cereal alternatives to summer fallow," in Proceedings of the Western Nutrient Management Conference 4, ed B. Brown (Brookings, SD: Potash and Phosphate Institute), 202-209.

Pan, W. L., Young, F. L., Maaz, T. M., and Huggins, D. R. (2016b). Canola integration into semi-arid wheat cropping systems of the inland Pacific Northwestern USA. Crop Pasture Sci. 67, 253-265. doi: 10.1071/CP15217

Pikul, J. L., Osborne, S. L., and Riedell, W. E. (2012). Corn yield and nitrogenand water-use under no-tillage rotations. Commun. Soil Sci. Plant Anal. 43, 2722-2734. doi: 10.1080/00103624.2012.719980

Pilbeam, C. J., Wood, M., Harris, H. C., and Tuladhar, J. (1998). Productivity and nitrogen use of three different wheat-based rotations in North West Syria. Aust. J. Agric. Res. 49, 451-458. doi: 10.1071/A97015

Ponisio, L. C., M'Gonigle, L. K., Mace, K. C., Palomino, J., de Valpine, P., and Kremen, C. (2015). Diversification practices reduce organic to conventional yield gap. Proc. R. Soc. B 282:20141396. doi: 10.1098/rspb.2014.1396

Powlson, D. S., Stirling, C. M., Jat, M. L., Gerard, B. G., Palm, C. A., Sanchez, P. A., et al. (2014). Limited potential of no-till agriculture for climate change mitigation. Nat. Clim. Change 4, 678-683. doi: 10.1038/nclimate,2292

$\mathrm{R}$ Core Team (2016). R: A Language and Environment for Statistical Computing. Vienna: R Foundation Statistical Computing. Available online at: http://www.R-project.org/

Roberts, T. L., and Johnston, A. M. (2007). "Tillage intensity, crop rotation, and fertilizer technology for sustainable wheat production North American experience," in Wheat Production in Stressed Environments. Developments in Plant Breeding, Vol. 12, eds H. T. Buck, J. E. Nisi, and N. Salomón (Dordrecht: Springer), 175-187.

Robertson, M., Kirkegaard, J., Peake, A., Creelman, Z., Bell, L., Lilley, J., et al. (2016). Trends in grain production and yield gaps in the high-rainfall zone of southern Australia. Crop Pasture Sci. 67, 921-937. doi: 10.1071/ $\mathrm{CP} 16153$

Rosenzweig, C., Elliott, J., Deryng, D., Ruane, A. C., Müller, C., Arneth, A., et al. (2014). Assessing agricultural risks of climate change in the 21 st century in a global gridded crop model intercomparison. Proc. Natl. Acad. Sci. U.S.A. 111, 3268-3273. doi: 10.1073/pnas. 1222463110

Ryan, J., Singh, M., and Pala, M. (2008). "Long-term cereal-based rotation trials in the Mediterranean region: Implications for cropping sustainability," in Advances in Agronomy (Academic Press), 273-319. Available online at: http:// www.sciencedirect.com/science/article/pii/S0065211307000077 (Accessed December 10, 2016).

Ryan, M. H., Norton, R. M., Kirkegaard, J. A., McCormick, K. M., Knights, S. E., Angus, J. F., et al. (2002). Increasing mycorrhizal colonisation does not improve growth and nutrition of wheat on Vertosols in south-eastern Australia. Crop Pasture Sci. 53, 1173-1181. doi: 10.1071/AR02005

Schillinger, W. F. (2016). Seven rainfed wheat rotation systems in a drought-prone Mediterranean climate. Field Crops Res. 191, 123-130. doi: 10.1016/j.fcr.2016.02.023

Schillinger, W. F., and Bolton, F. E. (1993). Fallow water storage in tilled vs. untilled soils in the Pacific Northwest. J. Prod. Agric. 6, 267-269. doi: 10.2134/jpa1993.0267

Schillinger, W. F., Kennedy, A. C., and Young, D. L. (2007). Eight years of annual no-till cropping in Washington's winter wheat-summer fallow region. Agric. Ecosyst. Environ. 120, 345-358. doi: 10.1016/j.agee.2006.10.017
Schillinger, W. F., and Papendick, R. I. (2008). Then and now: 125 years of dryland wheat farming in the Inland Pacific Northwest. Agron. J. 100, S166-S182. doi: 10.2134/agronj2007.0027c

Schillinger, W. F., and Paulitz, T. C. (2014). Natural suppression of rhizoctonia bare patch in a long-term no-till cropping systems experiment. Plant Dis. 98, 389-394. doi: 10.1094/PDIS-04-13-0420-RE

Schillinger, W. F., Schofstoll, S. E., and Alldredge, J. R. (2008). Available water and wheat grain yield relations in a Mediterranean climate. Field Crops Res. 109, 45-49. doi: 10.1016/j.fcr.2008.06.008

Schillinger, W. F., and Young, D. L. (2004). Cropping systems research in the world's driest rainfed wheat region. Agron. J. 96, 1182-1187. doi: 10.2134/agronj2004.1182

Seymour, M., Kirkegaard, J. A., Peoples, M. B., White, P. F., and French, R. J. (2012). Break-crop benefits to wheat in Western Australia - insights from over three decades of research. Crop Pasture Sci. 63, 1-16. doi: 10.1071/CP11320

Singh, P., Sharratt, B., and Schillinger, W. F. (2012). Wind erosion and PM10 emission affected by tillage systems in the world's driest rainfed wheat region. Soil Tillage Res. 124, 219-225. doi: 10.1016/j.still.2012.06.009

Smith, P., and Olesen, J. E. (2010). Synergies between the mitigation of, and adaptation to, climate change in agriculture. J. Agric. Sci. 148, 543-552. doi: $10.1017 /$ S0021859610000341

Snapp, S. S., Gentry, L. E., and Harwood, R. (2010). Management intensity - not biodiversity - the driver of ecosystem services in a long-term row crop experiment. Agric. Ecosyst. Environ. 138, 242-248. doi: $10.1016 /$ j.agee.2010.05.005

Soon, Y. K., and Arshad, M. A. (2004). Contribution of di-nitrogen fixation by pea to the productivity and $\mathrm{N}$ budget of a wheat-based cropping system. J. Agric. Sci. 142, 629-637. doi: 10.1017/S002185960500482X

Sullivan, L. S., Young, F. L., Smiley, R. W., and Alldredge, J. R. (2013). Weed and disease incidence in no-till facultative wheat in the Pacific Northwest, USA. Crop Prot. 53, 132-138. doi: 10.1016/j.cropro.2013.06.013

Soil Survey Staff, Natural Resources Conservation Service and United States Department of Agriculture (2016). Web Soil Survey. Available online at: https://websoilsurvey.sc.egov.usda.gov/ (Accessed February 22, 2017).

Tanaka, D. L., Anderson, R. L., and Rao, S. C. (2005). Crop sequencing to improve use of precipitation and synergize crop growth. Agron. J. 97, 385-390. doi: 10.2134/agronj2005.0385

Tanaka, D. L., Krupinsky, J. M., Liebig, M. A., Merrill, S. D., Ries, R. E., Hendrickson, J. R., et al. (2002). Dynamic cropping systems. Agron. J. 94, 957-961. doi: 10.2134/agronj2002.0957

Thorne, M. E., Young, F. L., Pan, W. L., Bafus, R., and Alldredge, J. R. (2003). No-till spring cereal cropping systems reduce wind erosion susceptibility in the wheat/fallow region of the pacific northwest. J. Soil Water Conserv. 58, 250-257. Available online at: https://naldc.nal.usda.gov/download/48775/PDF

Tilman, D. (1999). Global environmental impacts of agricultural expansion: the need for sustainable and efficient practices. Proc. Natl. Acad. Sci. U.S.A. 96, 5995-6000. doi: 10.1073/pnas.96.11.5995

Tilman, D., Balzer, C., Hill, J., and Befort, B. L. (2011). Global food demand and the sustainable intensification of agriculture. Proc. Natl. Acad. Sci. U.S.A. 108, 20260-20264. doi: 10.1073/pnas.1116437108

Unakitan, G., Hurma, H., and Yilmaz, F. (2010). An analysis of energy use efficiency of canola production in Turkey. Energy 35, 3623-3627. doi: 10.1016/j.energy.2010.05.005

Walden, V. (2014). Weather, Climate, and Agriculture. Regional Approaches to Climate Change for Pacific Northwest.

Walsh, C. L., and Johnson-Maynard, J. L. (2016). Earthworm distribution and density across a climatic gradient within the Inland Pacific Northwest cereal production region. Appl. Soil Ecol. 104, 104-110. doi: 10.1016/j.apsoil.2015.12.010

Williams, J. D., and Robertson, D. S. (2016). Soil water in small drainages farmed with no-tillage and inversion tillage in northeastern Oregon. J. Soil Water Conserv. 71, 503-511. doi: 10.2489/jswc.71.6.503

Williams, J. D., Wuest, S. B., and Long, D. S. (2014). Soil and water conservation in the Pacific Northwest through no-tillage and intensified crop rotations. J. Soil Water Conserv. 69, 495-504. doi: 10.2489/jswc.69.6.495

Wuest, S. B., and Schillinger, W. F. (2011). Evaporation from high residue no-till versus tilled fallow in a dry summer climate. Soil Sci. Soc. Am. J. 75, 1513-1519. doi: 10.2136/sssaj2010.0368 
Yang, C., Subtropical, A. R. C., Peterson, C. L., Shropshire, G. J., and Otawa, T. (1998). Spatial variability of field topography and wheat yield in the Palouse region of the Pacific Northwest. Trans. ASAE 41, 17-27.

Young, F. L. (2004). Long-term weed management studies in the Pacific Northwest. Weed Sci. 52, 897-903. doi: 10.1614/WS-04-014R

Young, F. L., Alldredge, J. R., Pan, W. L., and Hennings, C. (2015). Comparisons of annual no-till spring cereal cropping systems in the Pacific Northwest. Crop Forage Turfgrass Manag. 1, 1-7. doi: 10.2134/cftm2014.0089

Zentner, R. P., and Campbell, C. A. (1988). First 18 Years of a long-term crop rotation study in southwestern Saskatchewan - Yields, grain protein, and economic performance. Can. J. Plant Sci. 68, 1-21. doi: 10.4141/cjps88-001

Zentner, R. P., Campbell, C. A., Biederbeck, V. O., Miller, P. R., Selles, F., and Fernandez, M. R. (2001). In search of a sustainable cropping system for the semiarid Canadian Prairies. J. Sustain. Agric. 18, 117-136. doi: 10.1300/J064v18n02_10

Zentner, R. P., Campbell, C. A., Selles, F., Jefferson, P. G., Lemke, R., McConkey, B. G., et al. (2006). Effect of fallow frequency, flexible rotations, legume green manure, and wheat class on the economics of wheat production in the Brown soil zone. Can. J. Plant Sci. 86, 413-423. doi: 10.4141/ P05-081

Zentner, R. P., Campbell, C. A., Selles, F., McConkey, B. G., Jefferson, P. G., and Lemke, R. (2003). Cropping frequency, wheat classes and flexible rotations: effects on production, nitrogen economy, and water use in a Brown Chernozem. Can. J. Plant Sci. 83, 667-680. doi: 10.4141/P02-160
Zentner, R. P., Lafond, G. P., Derksen, D. A., and Campbell, C. A. (2002a). Tillage method and crop diversification: effect on economic returns and riskiness of cropping systems in a Thin Black Chernozem of the Canadian Prairies. Soil Tillage Res. 67, 9-21. doi: 10.1016/S0167-1987(02)00028-4

Zentner, R. P., Lafond, G. P., Derksen, D. A., Nagy, C. N., Wall, D. D., and May, W. E. (2004). Effects of tillage method and crop rotation on non-renewable energy use efficiency for a thin Black Chernozem in the Canadian Prairies. Soil Tillage Res. 77, 125-136. doi: 10.1016/j.still.2003.11.002

Zentner, R. P., Wall, D. D., Nagy, C. N., Smith, E. G., Young, D. L., Miller, P. R., et al. (2002b). Economics of crop diversification and soil tillage opportunities in the Canadian prairies. Agron. J. 94, 216-230. doi: 10.2134/agronj 2002.0216

Conflict of Interest Statement: The authors declare that the research was conducted in the absence of any commercial or financial relationships that could be construed as a potential conflict of interest.

Copyright (๑) 2017 Maaz, Schillinger, Machado, Brooks, Johnson-Maynard, Young, Young, Leslie, Glover, Madsen, Esser, Collins and Pan. This is an open-access article distributed under the terms of the Creative Commons Attribution License (CC BY).

The use, distribution or reproduction in other forums is permitted, provided the original author(s) or licensor are credited and that the original publication in this journal is cited, in accordance with accepted academic practice. No use, distribution or reproduction is permitted which does not comply with these terms. 


\section{APPENDIX 1}

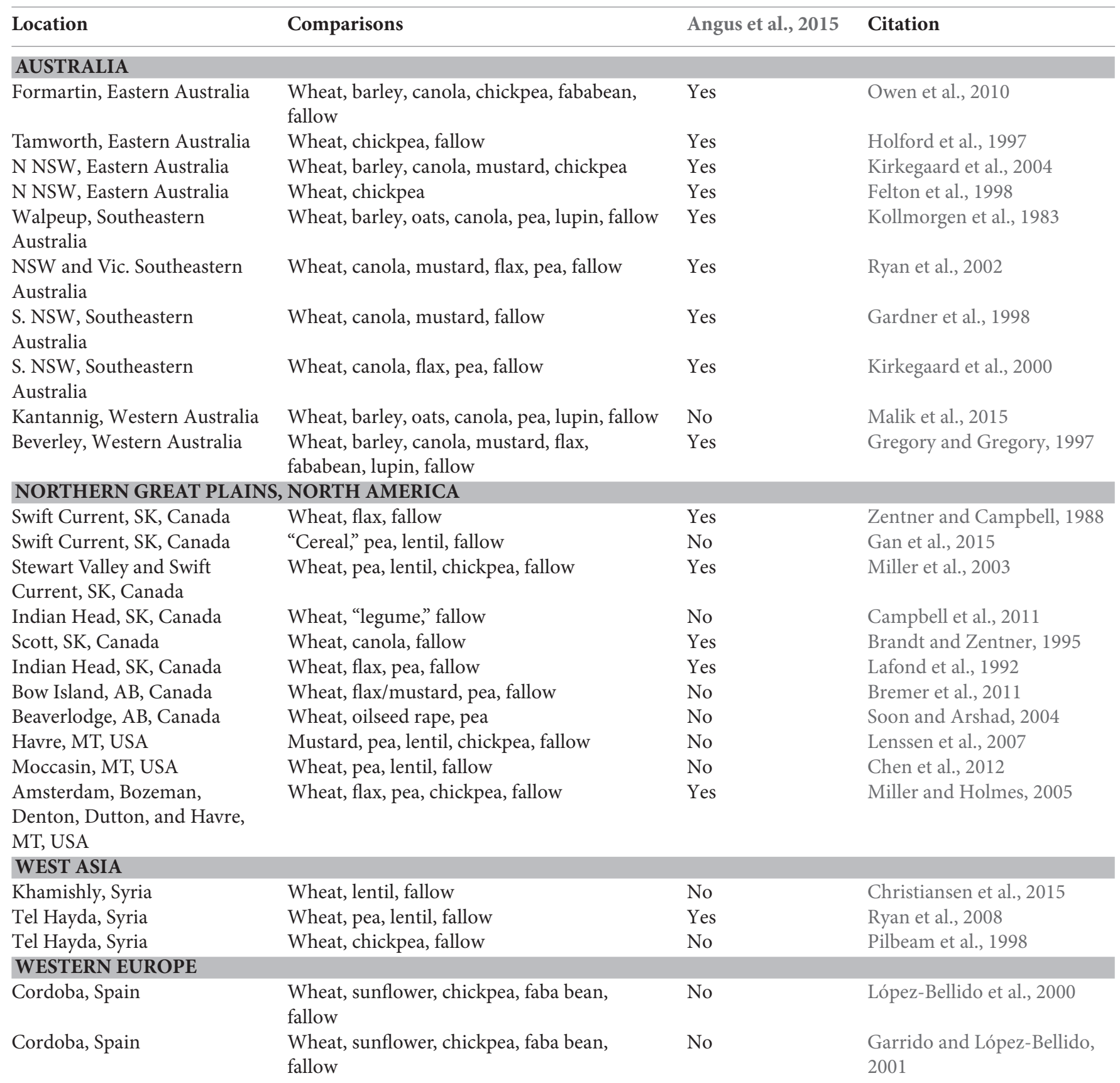

